\title{
Not All Laws are Created Equal: Legal Differences in State Non-Discrimination Laws and the Impact of LGBT Employment Protections
}

\author{
Ian Burn ${ }^{1}$ (D)
}

Published online: 30 August 2018

(C) The Author(s) 2018

\begin{abstract}
In this paper, I study the impact of legal differences in state employment nondiscrimination acts (ENDAs) for gay men and lesbian women on labor market outcomes. Employing a DDD approach, I show that enacting an employment nondiscrimination act is associated with increased wages of gay men and decreased employment of lesbian women. If all employment non-discrimination acts are treated as identical, these laws increased the hourly wages of gay men by $2.7 \%$ and decreased the employment of lesbian women by $1.7 \%$ and their hours worked by 0.7 hours. The results show that the strength of the law can result in heteroge-neous effects of the laws for gay men, but not for lesbian women. ENDAs with both punitive and compensatory damage provisions resulted in smaller wage increases for gay men than ENDAs with only compensatory damage provisions. ENDAs with longer statutes of limitations for complaints increased the employment of gay men, whereas laws with shorter statutes of limitations decreased employment. Based on the estimates from the state-level employment non-discrimination acts, I argue that extending federal protections under Title VII would lead to a small increase in the wages of gay men, but would significantly reduce the employment of lesbian women.
\end{abstract}

Keywords Discrimination · Law and economics · LGBT population

JEL Classification $\mathrm{J} 15 \cdot \mathrm{J} 31 \cdot \mathrm{J} 78 \cdot \mathrm{K} 31$

Ian Burn

ian.burn@sofi.su.se

1 Swedish Institute for Social Research, Stockholm University, Stockholm, Sweden 


\section{Introduction}

Beginning with Badgett (1995), researchers have accumulated evidence of disparities in the labor market outcomes between homosexuals and heterosexuals. Research has found gay men are paid less than heterosexual men (Klawitter 2015). The evidence of a gay wage gap exists across different datasets and is robust to various methods for identifying who is gay (Klawitter 2015). ${ }^{1}$ There is inconclusive evidence of wage differentials for lesbian women, with differences in fertility and selection into the labor market potentially explaining the differences (Klawitter 2015). ${ }^{2}$ In addition to the evidence of disparities in pay, there is consistent evidence from resume correspondence studies that heterosexuals are preferred by hiring managers to homosexuals (Bailey et al. 2013; Mishel 2016; Tilcsik 2011).

Historically, the policy implemented in the United States to reduce these disparities has been to make it illegal for an employer to discriminate against individuals based on their membership in a protected group. When employment nondiscrimination acts work as intended, the labor market outcomes of the protected group gradually improve, as appears to have happened for black men (Collins 2003; Donohue and Heckman 1991; Landes 1968; Neumark and Stock 2006). In other cases, however, the increased protections may make the protected group relatively more expensive to hire and terminate. Therefore, employers may reduce the number of employees they hire from the protected group (Bloch 1994), as may have happened for women and older workers (Beegle and Stock 2003; Lahey 2008; Neumark and Stock 2006). ${ }^{3}$

Despite an increasing number of states passing laws to protect gay men and lesbian women, there is little research on how effective these policies have been at reducing disparities. The research on LGBT non-discrimination acts has found mixed evidence for the effectiveness of employment protections at the state level (Baumle and Poston 2011; Klawitter and Flatt 1998, 2011; Martell 2013). ${ }^{4}$ In each of these

\footnotetext{
${ }^{1}$ Klawitter (2015) is a meta-study of the wage differentials for gay men and lesbian women. The metastudy shows that despite the large variance in the estimates, there is consistent evidence of a wage penalty for gay men. See Allegretto and Arthur (2001), Antecol et al. (2008), Black et al. (2003), Blandford (2003), Carpenter (2004), Cushing-Daniels and Yeung (2009), Elmslie and Tebaldi (2007), and Sabia and Orientation (2014) for more detailed discussions of the gay wage penalty.

${ }^{2}$ See Klawitter (2015) for the results of the meta-study for the lesbian wage differential. Antecol and Steinberger (2013) and Jepsen (2007) contain more specifics of the challenges in estimating the lesbian wage differential.

${ }^{3}$ Though it should be noted, the presence of negative employment effects and whether they are shortterm or long-term effects is a heavily debated topic in the literature (Acemoglu and Angrist 2001; Adams 2004; Beegle and Stock 2003; DeLeire 2000; Jolls and Prescott 2004; Kruse and Schur 2003; Lahey 2008; Neumark and Stock 1999).

${ }^{4}$ Klawitter and Flatt (1998) found there was no effect of employment protections on the wage or employment differences between cohabiting homosexuals and heterosexuals using the 1990 Census. Klawitter (2011) and Baumle and Poston (2011) revisited the question using 2000 Census data. In both papers, the authors found that ENDAs had no impact on the labor market outcomes of lesbian women. Baumle and Poston (2011) found that ENDAs increased the annual earnings of gay men by $2.6 \%$, but Klawitter (2011) showed this was due to ENDAs increasing weeks worked. Using the General Social Surveys, Martell (2013) found that employment non-discrimination laws decrease the wage gap between gay men and heterosexual men.
} 
Table 1 States with each legal provision in its ENDA

\begin{tabular}{|c|c|c|}
\hline & 2000 & 2012 \\
\hline ENDA law & 12 & 22 \\
\hline Damage awards & 2000 & 2012 \\
\hline Equitable relief & 12 & 22 \\
\hline Compensatory damages & 11 & 20 \\
\hline Punitive damages & 9 & 14 \\
\hline Attorney's fees & 10 & 19 \\
\hline Statute of limitations & 2000 & 2012 \\
\hline 120 Days & 0 & 1 \\
\hline 180 Days & 7 & 12 \\
\hline 300 Days & 3 & 4 \\
\hline 365 Days & 3 & 5 \\
\hline Employer size minimums & 2000 & 2012 \\
\hline 1 Employee & 6 & 9 \\
\hline 3 Employees & 1 & 1 \\
\hline 4 Employees & 1 & 4 \\
\hline 5 Employees & 1 & 1 \\
\hline 6 Employees & 2 & 2 \\
\hline 8 Employees & 0 & 1 \\
\hline 15 Employees & 1 & 4 \\
\hline
\end{tabular}

Note: Information on state laws comes from Sears et al. (2009), the Government Accountability Office (2013), and information from state laws collected by the author

papers, the authors assumed that all laws were identical, but there evidence of wide variation in how these state laws are constructed. When comparing state laws, the differences appear on three issues: who is protected under the law, how a complaint is resolved, and what damages and remedies are available for plaintiffs. Within these three groups of differences, there are thirteen provisions over which states differ. Table 1 details the areas where the laws diverge. In this paper, I focus on damage availability $^{5}$, employer size minimums ${ }^{6}$, and the statute of limitations ${ }^{7}$.

\footnotetext{
${ }^{5}$ There are three categories of damages: equitable relief, compensatory damages, and punitive damages. All states allow for equitable relief. Eighteen states provide for compensatory damages in their laws. Thirteen states provide for punitive damage in their statutes. In eighteen states, a successful plaintiff may recoup attorney's fees as part of the damage awards.

${ }^{6}$ The minimums range from one employee to fifteen employees. In nine states, all employers are covered. There are four states with a size minimum of 15 employees

${ }^{7}$ The average statute of limitations in states with an ENDA is 241 days (approximately eight months). States range from 120 days to 365 days.
} 
These legal differences are important because they determine the expected cost of discriminating for employers. The expected cost of discriminating can be increased either by increasing the probability that an employer is sued or by increasing the cost of being sued. The probability that an employer is sued potentially increases when employees are given longer to file a complaint and they can recoup their attorney's fees in a successful lawsuit (which lowers the cost of a lawsuit). Stronger damage provisions increase the expected cost of discriminating since employers who do discriminate face stiffer penalties if caught. Despite being limited to studying the effect of a state law being stronger than the federal law, previous work on nondiscrimination laws has shown that heterogeneity in the laws can impact the effect. ${ }^{8}$ Jolls and Prescott (2004) used state-level variation in disability discrimination laws to show that the negative employment effects of the Americans with Disabilities Act (ADA) were primarily due to "reasonable accommodations" requirements and not firing costs. Neumark and Button (2014) showed that stronger state-level laws against age discrimination might have reduced the hiring of older workers during the Great Recession.

In this paper, I use a differences-in-differences-in-differences methodology to identify how the passage of ENDAs impacted the labor market outcomes of gay men and lesbian women. Since ENDAs are designed to benefit gay men and lesbian women, the first difference is a comparison of the labor market outcomes of gay men and lesbian women relative to gay men and lesbian women in states that have not passed a law. Because there may be non-ENDA related factors that affect wages and employment, I use the difference in labor market outcomes between gay men and lesbians and heterosexuals in the same state to account for changes in these differentials that are unrelated to the passage of an ENDA. The triple difference estimation results in a comparison of how the labor market outcomes between heterosexuals and homosexuals in a state changed after the passage of an ENDA relative to the differences in states that did not pass an ENDA. My results indicate that after an ENDA had been passed, hourly wages for cohabiting gay men rose $2.7 \%$. There was no significant effect on annual income from wages, employment, or hours worked for gay men. For lesbian women, the results are less positive. The passage of an ENDA had no significant effect on the wage differentials for lesbian women, but was associated with a $1.7 \%$ decline in the employment and a 0.733 -hour decline in hours worked.

The results also show the benefits of the law were dependent on the structure of the law. For gay men in states where successful plaintiffs cannot be awarded damages, there was no effect of an ENDA. Gay men in states that only allow compensatory damages experienced an increase in annual wages of $12.3 \%$ and an increase in hourly wages of $15.5 \%$. Gay men in states that allow both compensatory damages and punitive damages experienced an increase in annual wages of $7.9 \%$ and an increase in hourly wages of $7.4 \%$. In states with longer complaint periods, I find small increases in the employment of gay men. After controlling for the differences in provisions, the average ENDA decreased the annual income of lesbian women by $11.4 \%$. Allowing

\footnotetext{
${ }^{8}$ If there is a federal law banning discrimination, it creates a lower bound on the state laws. Any state law that provides weaker protections than the federal law would be superseded by the federal law.
} 
for punitive damages decreased the hours worked for lesbian women by an additional 0.850 hours.

\section{Data}

The data used in this paper comes from the 2008 through 2014 American Community Survey (ACS) 1-Year Samples, the 1990 U.S. Census 5\% Sample, and the 2000 U.S. Census 5\% Sample (Ruggles et al. 2010). A longitudinal database of all state laws was created using information from The Williams Institute at UCLA, the Government Accountability Office, and state laws (Government Accountability Office 2013; Sears et al. 2009; Sears and Mallory 2011).

To identify gay men and lesbian women in the United States, the Census collects information on householders and the relationships of everyone in the household to the householder. A same-sex couple is identified when the gender of the householder and the gender of the unmarried partner (or spouse) of the householder are the same. There is no information on single gay men and lesbian women in the Census data or ACS, only cohabiting gay men and lesbian women. Also missing from the sample are gay men and lesbian women in a household where one of the partners is not the household head (such as living with one's parents). Therefore, the sample in the analysis is restricted to comparisons between cohabiting individuals.

The sample used in the analysis begins with all adults older than 18 who claim to be the householder, spouse, or unmarried partner. In this paper, I focus on comparisons between cohabiting same-sex couples and married heterosexual couples. Cohabiting gay men and lesbian women are identified in the sample if they are cohabiting with an individual of the same gender. ${ }^{9}$ Once I identify cohabiting same-sex couples, I restrict the sample to individuals over the age of 22 and under the age of 65 . The age of 22 is selected to avoid school-aged individuals.

In the data, heterosexual couples are miscoded as same-sex cohabiting couples if the sex of one of the individuals is miscoded. Even though miscoding of sex is one of the least common errors made on Census forms, due to the small size of the gay and lesbian population, any miscoding in the heterosexual sample has the potential for increasing the number of gay men and lesbian women in a significant way (O'Connell and Golding 2006). When looking at the Census forms, researchers have that the miscoding is concentrated in the group of individuals who claimed to be married on their Census form and found smaller amounts of miscoding in the sample of same-sex couples who claim to be unmarried partners (O'Connell and Golding 2006; O'Connell and Loftquist 2009). Work on the wording of relationship questions in the ACS resulted in a large decline in the number of miscodings in the 2008 and subsequent surveys. Because before 2004 it was not possible for same-sex couples to be married, I exclude any gay or lesbian that had their marital status recoded in 2000

\footnotetext{
${ }^{9}$ Cohabiting is defined as either being married or in an unmarried partnership. Unmarried partnerships are defined as relationships where the unmarried partner shares a close personal relationship with the reference person.
} 


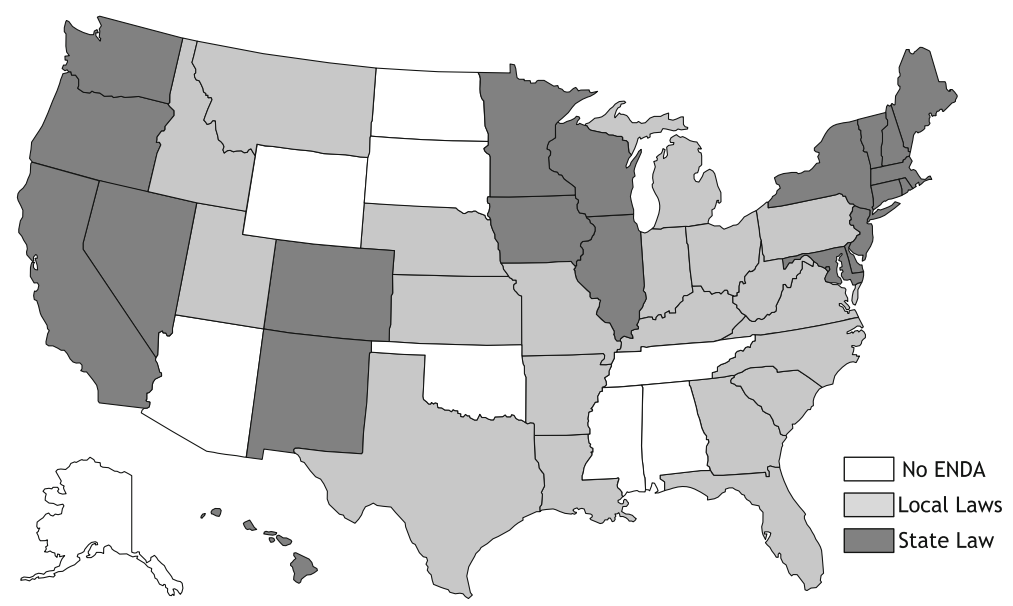

Fig. 1 Map of ENDA Laws in 2011 Note Data on state and local laws comes from Government Accountability Office (1997), Government Accountability Office (2013), Human Rights Campaign (2012), and Sears et al. (2009), and by reading the state laws themselves

from married to cohabiting. This is a conservative portioning of the cohabiting gay and lesbian population, but it reduces the measurement error.

The other concern is that the passage of ENDAs laws may induce gay men and lesbian women to move to these states. Previous research has found mixed evidence that gay men and lesbian women migrate in response to the passage of pro-gay laws. Ueno et al. (2014) found that gay men were no more likely than heterosexual men to migrate to a different state, but lesbian women are more likely than heterosexual women to move. When gay men and lesbian women do move, there is inconclusive evidence that gay rights laws influence their choices. Colvin and Riccucci (2002) found no evidence that when they migrated that cohabiting gay men and lesbian women were more likely to move to a state that had passed an ENDA. Beaudin (2017) found evidence that cohabiting gay men and lesbian women were more likely than cohabiting heterosexuals to move to states with marriage equality. Because Colvin and Riccucci (2002) was estimated using a five-year window (while Beaudin (2017) used a one-year window), the results may not be as useful in evaluating the risk of current migration biasing the results. To avoid the migration problem completely, I remove any individual who has migrated within the past year from the ACS data. ${ }^{10}$ This means that whenever possible (i.e., the latter half of the sample), the effect of an ENDA will only be identified off of the wages of individuals who have been in the state for more than a year.

The result of these restrictions on the data is that I am left with a sample of $6,128,130$ heterosexual men and 44,143 gay men for whom I observe labor market outcomes. Within the sample of gay men, 26,340 live in states with no employment

\footnotetext{
${ }^{10}$ The Census data does not ask about migration status in the last year. Rather it asks where a respondent was living five years ago. This window is simply too large to use as a restriction to exclude individuals who potentially moved to take advantage of an ENDA.
} 
protections, and 17,803 live in a state with employment protections. For women, there are a total of 5,016,785 heterosexual women and 44,275 lesbian women. There are 26,170 lesbian women in states with no employment protections and 18,105 lesbian women in states with employment protections.

Information about provisions comes from state laws and reports compiled by the Williams Institute and the Government Accountability Office (Sears et al. 2009; Gov-

Table 2 Gay and lesbian wage differentials by year

\begin{tabular}{|c|c|c|c|}
\hline & $\begin{array}{l}\text { Men } \\
\text { All states } \\
\text { (1) }\end{array}$ & $\begin{array}{l}\text { ENDA } \\
(2)\end{array}$ & $\begin{array}{l}\text { No ENDA } \\
\text { (3) }\end{array}$ \\
\hline 1990 & $\begin{array}{l}-0.126^{* * *} \\
(0.008)\end{array}$ & $\begin{array}{l}-0.123^{* * *} \\
(0.012)\end{array}$ & $\begin{array}{l}-0.130^{* * *} \\
(0.010)\end{array}$ \\
\hline 2000 & $\begin{array}{l}-0.089^{* * *} \\
(0.013)\end{array}$ & $\begin{array}{l}-0.068^{* * *} \\
(0.015)\end{array}$ & $\begin{array}{l}-0.114^{* * *} \\
(0.012)\end{array}$ \\
\hline 2008 & $\begin{array}{l}-0.072^{\text {*** }} \\
(0.018)\end{array}$ & $\begin{array}{l}-0.034 \\
(0.025)\end{array}$ & $\begin{array}{l}-0.114^{* * *} \\
(0.014)\end{array}$ \\
\hline 2009 & $\begin{array}{l}-0.075^{\text {*** }} \\
(0.011)\end{array}$ & $\begin{array}{l}-0.063 \\
(0.013)\end{array}$ & $\begin{array}{l}-0.114^{* * *} \\
(0.014)\end{array}$ \\
\hline 2010 & $\begin{array}{l}-0.061^{\text {*** }} \\
(0.016)\end{array}$ & $\begin{array}{l}-0.042 \\
(0.024)\end{array}$ & $\begin{array}{l}-0.081^{\text {*** }} \\
(0.014)\end{array}$ \\
\hline 2011 & $\begin{array}{l}-0.073^{\text {*** }} \\
(0.011)\end{array}$ & $\begin{array}{l}-0.065^{* * *} \\
(0.012)\end{array}$ & $\begin{array}{l}-0.081^{* * *} \\
(0.017)\end{array}$ \\
\hline 2012 & $\begin{array}{l}-0.054^{* * *} \\
(0.014)\end{array}$ & $\begin{array}{l}-0.036^{*} \\
(0.017)\end{array}$ & $\begin{array}{l}-0.074^{* * *} \\
(0.015)\end{array}$ \\
\hline 2013 & $\begin{array}{l}-0.069^{* * *} \\
(0.014)\end{array}$ & $\begin{array}{l}-0.044^{*} \\
(0.019)\end{array}$ & $\begin{array}{l}-0.089^{* * *} \\
(0.019)\end{array}$ \\
\hline 2014 & $\begin{array}{l}-0.079^{* * *} \\
(0.018) \\
\text { Women }\end{array}$ & $\begin{array}{l}-0.021 \\
(0.015)\end{array}$ & $\begin{array}{l}-0.132^{* * *} \\
(0.016)\end{array}$ \\
\hline 1990 & $\begin{array}{l}0.022 \\
(0.013)\end{array}$ & $\begin{array}{l}0.032 \\
(0.017)\end{array}$ & $\begin{array}{l}0.003 \\
(0.015)\end{array}$ \\
\hline 2000 & $\begin{array}{l}0.031^{\text {*** }} \\
(0.008)\end{array}$ & $\begin{array}{l}0.030^{* * *} \\
(0.011)\end{array}$ & $\begin{array}{l}0.032^{* *} \\
(0.011)\end{array}$ \\
\hline 2008 & $\begin{array}{l}0.062^{* * *} \\
(0.010)\end{array}$ & $\begin{array}{l}0.058^{* * *} \\
(0.013)\end{array}$ & $\begin{array}{l}0.064^{* * *} \\
(0.016)\end{array}$ \\
\hline 2009 & $\begin{array}{l}0.051^{\text {*** }} \\
(0.010)\end{array}$ & $\begin{array}{l}0.049^{* *} \\
(0.012)\end{array}$ & $\begin{array}{l}0.052^{* *} \\
(0.014)\end{array}$ \\
\hline 2010 & $\begin{array}{l}0.056^{* * *} \\
(0.009)\end{array}$ & $\begin{array}{l}0.045^{* *} \\
(0.014)\end{array}$ & $\begin{array}{l}0.068^{* * *} \\
(0.011)\end{array}$ \\
\hline 2011 & $\begin{array}{l}0.050^{* *} \\
(0.011)\end{array}$ & $\begin{array}{l}0.059^{* *} \\
(0.015)\end{array}$ & $\begin{array}{l}0.038^{* *} \\
(0.011)\end{array}$ \\
\hline
\end{tabular}


Table 2 (continued)

\begin{tabular}{llll}
\hline 2012 & $0.029^{* *}$ & $0.034^{*}$ & $0.024^{*}$ \\
& $(0.010)$ & $(0.014)$ & $(0.011)$ \\
& $0.029^{*}$ & 0.016 & $0.040^{*}$ \\
2014 & $(0.011)$ & $(0.015)$ & $(0.015)$ \\
& $0.025^{*}$ & $0.042^{* *}$ & 0.013 \\
& $(0.010)$ & $(0.012)$ & $(0.015)$ \\
\hline
\end{tabular}

$* * * \mathrm{p}<0.001$, ** $\mathrm{p}<0.01, * \mathrm{p}<0.05$

Note Author's calculations based on data from the 2010 and 2014 American Community Surveys 1\% PUMS, the 1990 Decennial Census 5\% PUMS, and the 2000 Decennial Census 5\% PUMS. The outcome variable in this table is log hourly wages. Hourly wages are in constant 1999 dollars. Reported here are the estimated wage differentials after splitting the sample by year and by legal status and estimating the wage differential between heterosexuals and homosexuals in each sub-sample. The 2008, 2009, and 20112013 American Community Surveys are not used in this analysis. The coefficients correspond to the interaction of being gay or lesbian and the year dummy. All regressions are estimated using OLS and include demographic and occupation controls, state fixed effects, year fixed effects, and state-by-year fixed effects. For a full list of control variables, see Table 9. Standard errors clustered at the state level are in parentheses

ernment Accountability Office 2013). ${ }^{11}$ Wisconsin passed employment protections for gay men and lesbian women in 1982. In 1990, only Wisconsin, Massachusetts, and D.C. had employment protections for gay men and lesbian women. By 2000, the number of states had grown to twelve. In 2014, twenty-one states and Washington, D.C. had employment non-discrimination acts protecting gay men and lesbian women. As shown in Fig. 1, the Northeast, Midwest, and the West feature the highest concentration of these laws. ${ }^{12}$ Table 1 highlights how different each law is by comparing the frequency of different legal provisions. There does not appear to be a pattern between the strength of the law and the geographic distribution of states that have passed them.

\section{Estimation strategy}

The goal of this paper is to estimate the impact of employment non-discrimination acts on the labor market outcomes of cohabiting gay men. I focus on the relationship between the strength of the laws and the impact of the laws. Because the laws in question vary by state over time, I use the state and year variation to estimate a differences-in-differences-in-difference model. Since the passage of an ENDA does not impact heterosexuals, I can use the comparison of gay men and lesbian women

\footnotetext{
${ }^{11}$ Tables $10,11,12,13$, and 14 detail the differences between the state laws.

${ }^{12}$ The regional pattern of ENDAs suggests that the states that pass these laws may not be selected at random. In "Robustness Checks and Threats to Validity", I show how prejudice changes in a region before and after the passage of a law to test whether the timing of these laws is exogenous to changes in prejudice.
} 
and their married heterosexual counterparts to isolate the effect these laws have on the labor market outcomes of cohabiting gay men and lesbian women. I use a flexible model, saturated with year, state, and state-by-year fixed effects interacted with being homosexual:

$$
\begin{gathered}
Y_{i s t}=\beta_{0}+\beta_{1} \text { Homo }_{i s t}+\beta_{2}\left(\text { Homo }_{i s t} \times E N D A_{s t}\right)+I_{s} \gamma_{s}+I_{t} \gamma_{t} \\
+\left(I_{s} \times I_{t}\right) \gamma_{s t}+\left(\text { Homo }_{i s t} \times I_{s}\right) \theta_{H, s}+\left(\text { Homo }_{i s t} \times I_{t}\right) \theta_{H, t}+\mathbf{X}_{i s t}^{\prime} \delta+\epsilon_{i s t}
\end{gathered}
$$

$Y_{i s t}$ is the dependent variable of interest. In this paper, I look at log annual income from wages, log hourly wages, the probability of being employed, and hours worked. $H_{\text {omo }}$ ist is a dummy for being a cohabiting gay man or lesbian woman. ENDA $A_{s t}$ is a dummy for state $s$ having an employment non-discrimination act that protected gay men and lesbian women in year $t$. The vector $\mathbf{X}$ contains controls for demographic, occupation, and geographic variables that may affect wages or employment. See Appendix Table 9 for the full list of control variables.

Also included in the regression are state, year, and state-by-year fixed effects $\left(\gamma_{s}, \gamma_{t}\right.$, and $\left.\gamma_{s t}\right)$. These fixed effects will capture unobserved differences common to all observation in a state, year, and state-by-year cell. To account for the differences between cohabiting homosexuals and married heterosexuals that exist across states, state fixed effects are interacted with the dummy for cohabiting same-sex couples $\left(\theta_{H, s}\right)$. To account for common trends that affect cohabiting same-sex couples differently than heterosexual couples (e.g. declines in prejudice, business cycle fluctuations, etc.), year fixed effects are interacted with the dummy for cohabiting same-sex couples $\left(\theta_{H, t}\right)$. Due to individual preferences potentially being correlated within a state and treatment occurring at the state-level, the standard errors $(\epsilon)$ are clustered at the state-level.

I estimate the models for men and women separately. In the analysis of wages (both annual and hourly), the sample was restricted to individuals in the labor force. ${ }^{13}$ For the analysis of employment and hours worked per week, the sample of all adults is used.

In Eq. 1, the differential effect of being a cohabiting same-sex couple in the United States across all years is captured by $\beta_{1}$. How this differential changes over time is captured by $\theta_{H, t}$. The state fixed effects for cohabiting same-sex couples $\left(\theta_{H, s}\right)$ capture how the wage differential varies across states. The parameter of interest is $\beta_{2}$, which captures how the differential between homosexuals and heterosexuals in states with ENDAs changed after the passage of a law.

To interpret $\beta_{2}$ as being the causal effect of enacting employment protections for sexual orientation, it must be the case that there are no other factors related to changes in the gay-heterosexual wage differential in states that do and do not have LGBT employment protections. I test these assumptions in "Robustness Checks and Threats to Validity". In addition to testing the assumptions of the DDD model, I test how robust the results are to confounding factors, specifically same-sex marriage and

\footnotetext{
${ }^{13}$ To test the effect of ENDAs across the labor force, I split the sample by full-time and part-time work status as a robustness check.
} 
selection into the labor market. Results of the robustness checks are also reported in "Robustness Checks and Threats to Validity".

The main contribution of this paper is to test how the heterogeneity of the law affects the impact of these laws. To do this, I add a series of controls in Eq. 1 to capture policy differences in the state law. I estimate the following equation:

$$
\begin{aligned}
& Y_{i s t}=\beta_{0}+\beta_{1} \text { Homo }_{i s t}+\beta_{2}\left(\text { Homo }_{i s t} \times E N D A_{s t}\right)+\beta_{p}\left(\text { Homo }_{i s t} \times E N D A_{s t} \times P_{s, t}\right) \\
& +\mathbf{X}_{i s t}^{\prime} \delta+I_{s} \gamma_{s}+I_{t} \gamma_{t}+\left(I_{s} \times I_{t}\right) \gamma_{s t}+\left(\text { Homo }_{i s t} \times I_{s}\right) \theta_{H, s}+\left(\text { Homo }_{i s t} \times I_{t}\right) \theta_{H, t}+\epsilon_{i s t}
\end{aligned}
$$

where $P_{s, t}$ is a vector of policy variables. States rarely change their nondiscrimination laws, but there have been amendments or court cases that resulted in changes to the laws. ${ }^{14}$ The policy variables used here are the availability of damages (compensatory and punitive), the statute of limitations for complaints, the employer size minimum, and the ability to recoup attorney's fees. The availability of damages and the ability to recoup attorney's fees enter into Eq. 2 as dummy variables. The statute of limitations for complaints and employer size minimums have been normalized to the average value to make interpreting the coefficients easier. The average complaint period in a state with an ENDA is 245 days. State complaint periods are coded as the number of months relative to the average. The average size of firm size minimum for being covered by a law is five employees. For states with an ENDA, size minimums are coded as the employer size minimum minus five.

\section{Main Results}

In this section, I begin by discussing the effect of ENDAs on gay men and then move to discussing the results for lesbian women. For both groups, I first look at the average effect of the law before comparing the effects of different legal provisions. I focus on four labor market outcomes: log annual income from wages, log hourly wages, employment, and hours worked per week. ENDAs may increase the wages of gay men and lesbian women if the laws force employers to pay them the same wages they pay their heterosexual employees. These laws can also increase the employment of gay men and lesbian women if they make it easier for them to find a job. They may increase the hours worked if they allow gay men and lesbian women to obtain full-time employment or find a second job.

\footnotetext{
${ }^{14}$ See the tables about laws in the Appendix for details on how these provisions have changed within states over time. A case of this happening was Connecticut added compensatory damages to the list of remedies available after an appeals court ruled in 2000 that the statues prescription of "such legal and equitable relief which the court deems appropriate" and "attorney's fees and costs" included compensatory damages (Sears et al. 2009).
} 


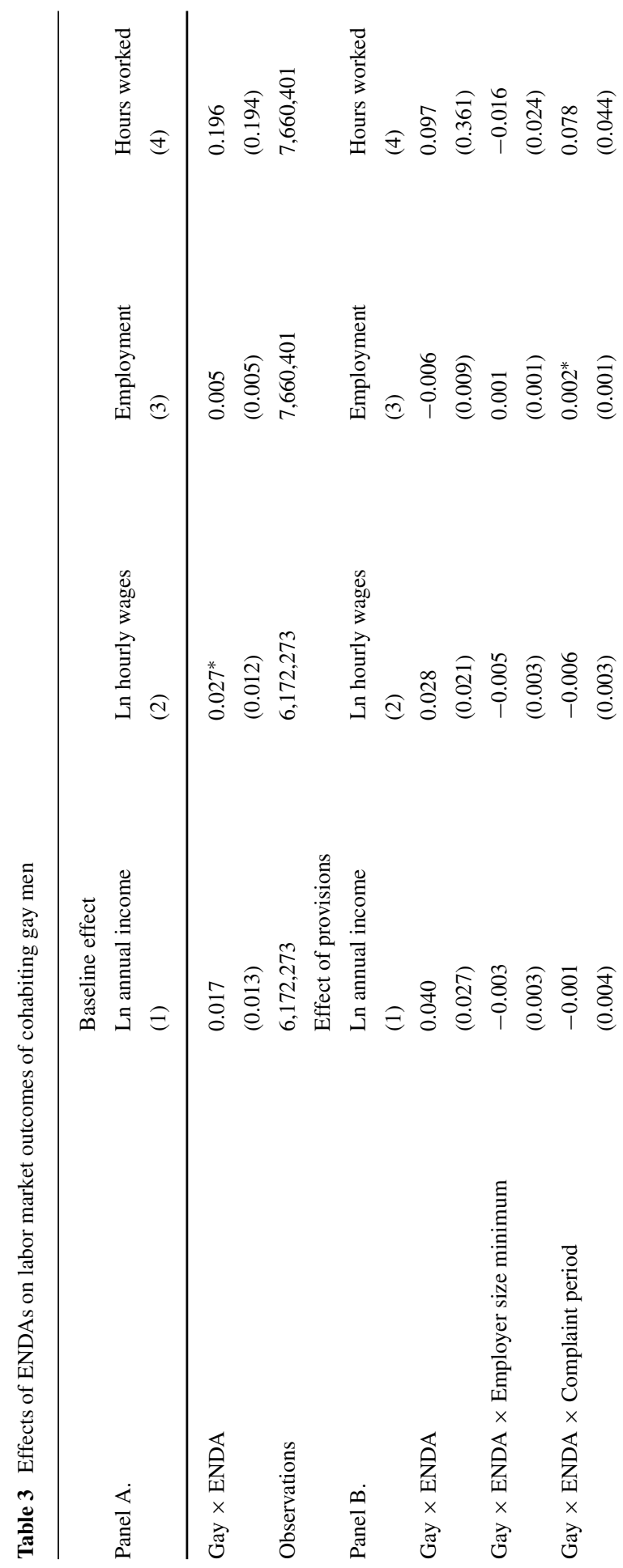




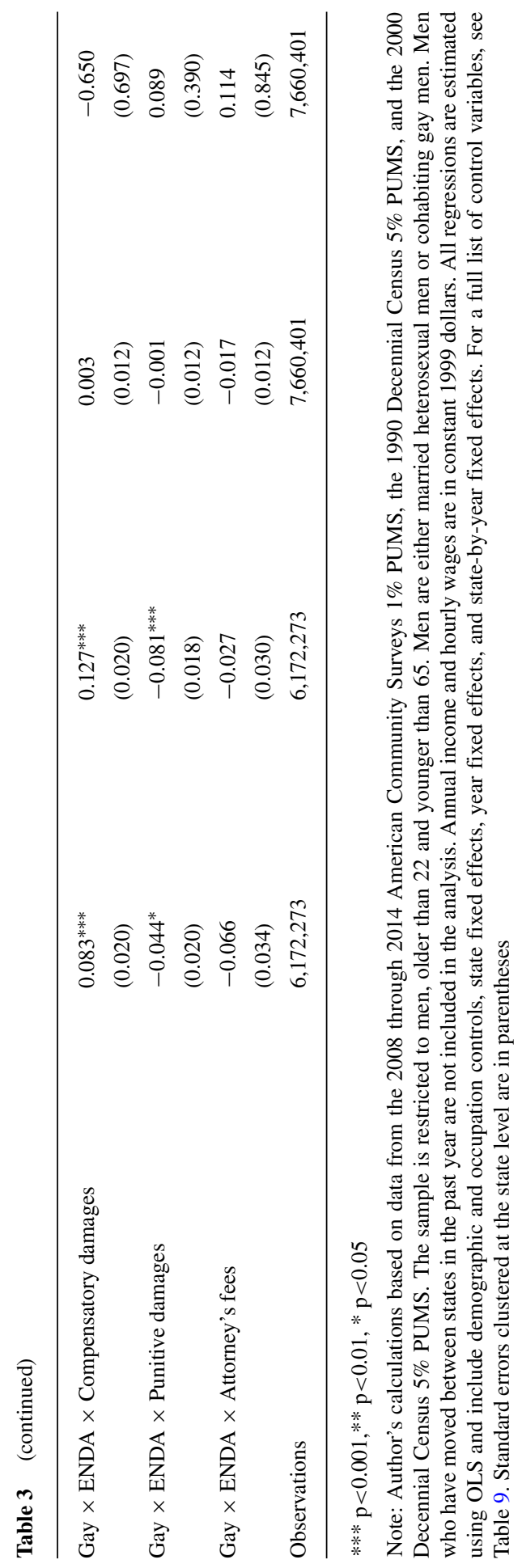


Table 2 reports the wage differential between heterosexuals and homosexuals by year in the sample. ${ }^{15}$ Similar to early research using the 1990 Census (Allegretto and Arthur 2001), I find gay men earned $12.6 \%$ less than a comparable heterosexual man in 1990, but this penalty declined by 4.7 percentage points between 1990 and 2014. The decline has been most pronounced in states with an ENDA. States with an ENDA saw a decline of 10.2 percentage points and states with no ENDA saw an increase of 0.2 percentage points. Lesbian women earned $2.2 \%$ more than a comparable heterosexual woman, and this has not changed much since 1990. States with ENDAs and without ENDAs did not see as stark differences in the wage differentials as was observed for gay men. Given that the initial conditions for gay men and lesbian women are different, then we expect there to be different effects for the two groups. If the wage differential is due to discrimination, then gay men would experience an increase in wages after the passage of a law and lesbians would experience a wage decline. If the wage premium that lesbian women experience is due to unobserved differences that are not discrimination, then we would expect the laws to have zero effect for gay men or lesbians. Since before the law lesbian women are favored and gay men are disfavored, it is not clear a priori whether we should expect the laws effects to be symmetric across the two groups.

I begin by looking at the effect of ENDAs on cohabiting gay men in Table 3 . In Panel A of Table 3, I replicate what the previous literature has done and use a single dummy variable for having an ENDA. The first column of Table 3 reports the results for log annual income, the second column reports the results for log hourly wages, the third column reports the results for employment, and the fourth column reports the results for usual hours worked per week. I find no effect of passing an ENDA on the log annual income of gay men. There was, however, a positive effect of passing an ENDA on log hourly wages. Between 1990 and 2014, the passage of an ENDA increased the hourly wages of cohabiting gay men by $2.7 \%$. This increase in hourly wages was statistically significant at the $5 \%$ level. Similar to results found in the previous literature, the passage of an ENDA had no significant effect on the employment of cohabiting gay men. ${ }^{16}$ I also find no statistically significant effect of the passage of an ENDA on hours worked per week. ${ }^{17}$

The results in Panel A suggest the declines in the wage penalty for gay men observed in Table 2 in states that passed an ENDA are due in part to the passage of these laws. In states with an ENDA, the wage penalty for gay men declined 10.2 percentage points between 1990 and 2014. The passage of ENDAs can explain 26\% of this decline (2.7\% divided by $10.2 \%)$.

\footnotetext{
${ }^{15}$ There is an extensive literature that discusses the nature of these wage differentials and whether they are driven by discrimination or other unobserved differences between the groups (Klawitter 2015), but from a legal perspective, the type of discrimination that leads to the observed wage penalty for gay men does not matter. The passage of an ENDA makes both statistical discrimination and taste-based discrimination illegal.

${ }^{16}$ The results reported in the paper are those from a linear probability model. The results using a probit are similar in magnitude and significance.

${ }^{17}$ While Klawitter (2011) looked at weeks worked per year in the 2000 Census, the ACS reports the usual weeks worked per year in discrete intervals, so I do not use this as an outcome.
} 
Panel B in Table 3 reports the effect each policy had on outcomes. Among states with ENDAs, the average size of firm size minimum for being covered by the law is five employees. Decreasing the firm size minimum by one employee relative to the average minimum will increase the number of firms that are covered by the law. For all the outcomes studied here, I find no significant effect of smaller firm size minimum. I find similar results for the complaint period. When I compare the effects of the complaint period across the different outcomes, I find that a longer statute of limitations only has a significant effect on employment. Increasing the complaint period by 1 -month above the average increases the employment of gay men by $0.2 \%$.

Where I find the strongest effects is in damages. Damages have a significant effect on both annual income and hourly wages. In states that allow compensatory damages, the annual income of gay men increase by $9.4 \%$, and the hourly wages of gay men increase by $12.7 \%$. When a state allows for punitive damages, the annual income of gay men falls by $4.4 \%$, and the hourly wages of gay men fall by $8.1 \%$. When looking at the damages provisions together, there is a distinct pattern of decreasing returns to strength. Providing for damages is important to the increase in earnings of gay men since it is a credible message to discriminating firms that there is a cost to engaging in discriminatory behavior. But, firms increase the wage of gay men less as the cost of discriminating increases. In states that allow only compensatory damages, there is a $12.8 \%$ net increase in annual wages. In states that allow both compensatory damages and punitive damages, there is an $8.8 \%$ net increase in annual wages. A similar pattern exists for hourly wages.

Table 4 shows the average effect of ENDAs for lesbian women appears similar to the effects found in earlier research on non-discrimination laws for women (Neumark and Stock 2006). In Panel A of Table 4, I show there was no increase in annual income or wages after the passage of the ENDA, consistent with what earlier work on ENDAs found for lesbian women (Klawitter and Flatt 1998; Klawitter 2011). My results for the employment effects for lesbian women show that ENDAs were detrimental to the employment of lesbian women, where Klawitter and Flatt (1998) and Klawitter (2011) found no effect. There was a 1.7\% decline in employment after an ENDA is passed. I also find a 0.733 -hour decline in hours worked for lesbian women.

The second panel of Table 4 explores how the legal provisions influence the effect of an ENDA for lesbian women. By breaking out the effect of an ENDA by provision, I show that for the most part there is no effect of the provisions on the wages or employment of lesbian women. There are two exceptions. First, after controlling for the differences in provisions, the average ENDA now has the effect of decreasing the annual income of lesbian women by $11.4 \%$. The specific provisions do not appear to mitigate this effect, suggesting this result is driven by correlations amongst the provisions. Second, I find that stronger damages may further decrease the employment of lesbian women. Allowing for punitive damages decreases the hours worked for lesbian women by an additional 0.850 hours.

These costs and benefits of ENDAs for gay men and lesbian women are not spread evenly across the labor force. In Table 5, I compare the effect of ENDAs on wages for 


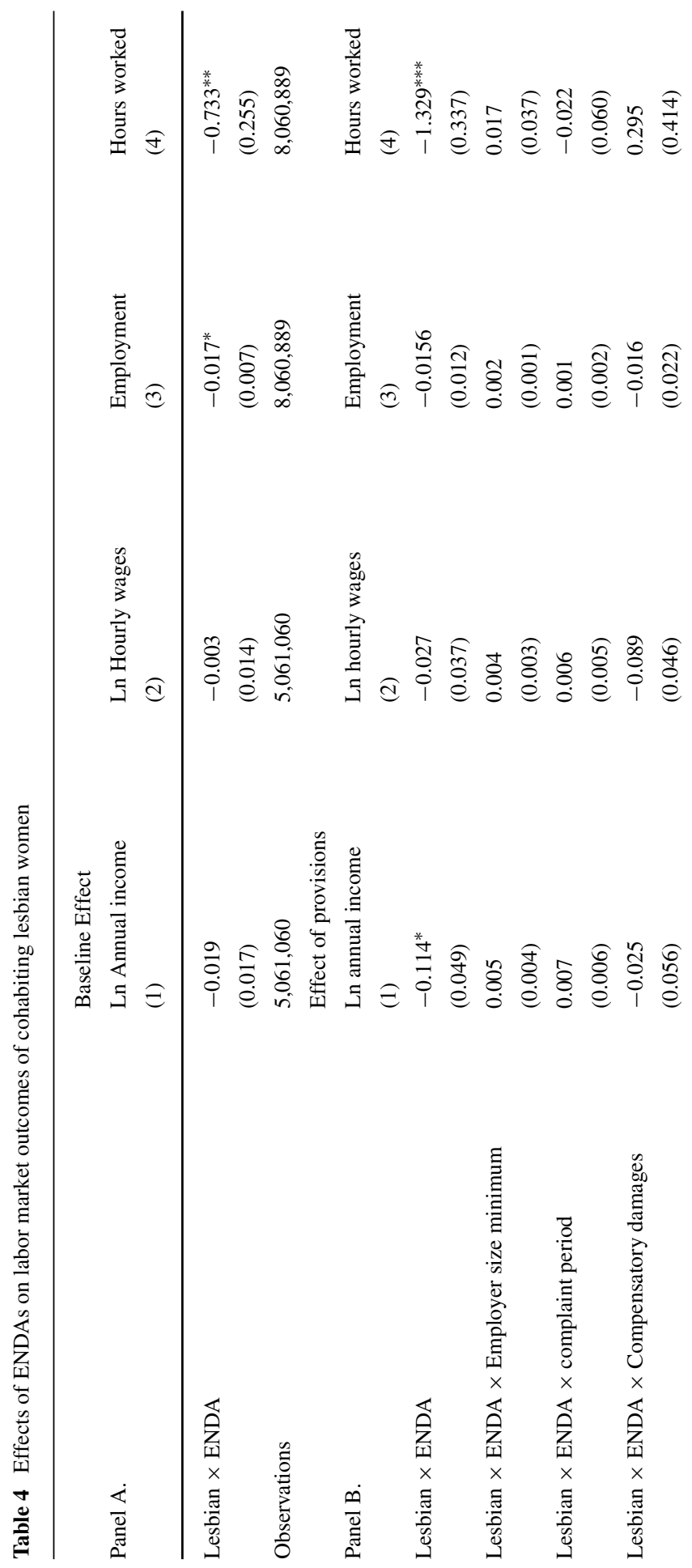




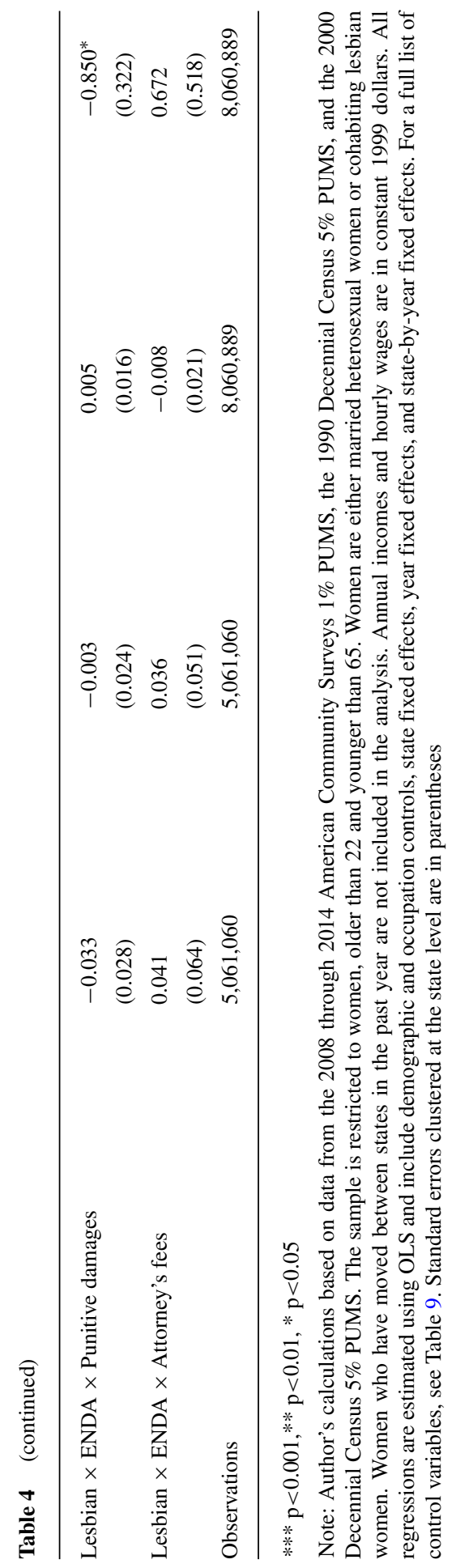




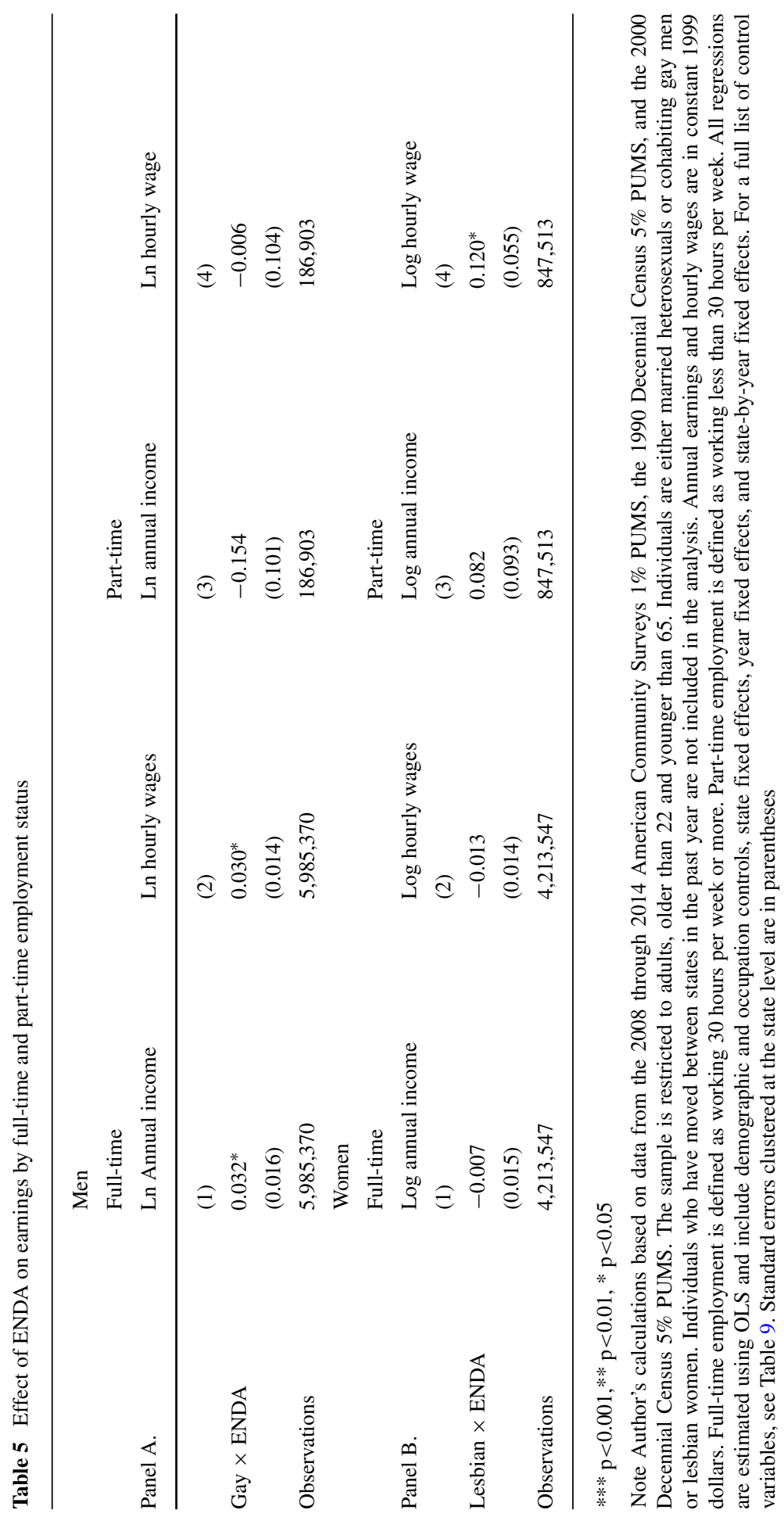


Table 6 Questions from the general social survey

\begin{tabular}{ll}
\hline Question & Question text \\
\hline SEX & What about sexual relations between two adults of the same sex- \\
& do you think it is always wrong, almost always wrong, wrong only \\
& sometimes, or not wrong at all? \\
& Asked between 1990 and 2014 \\
& GSS Mnemonic: HOMOSEX \\
If some people in your community suggested that a book he wrote \\
in favor of homosexuality should be taken out of your public library, \\
would you favor removing this book, or not? \\
Asked between 1990 and 2014 \\
GSS Mnemonic: LIBHOMO \\
Suppose this admitted homosexual wanted to make a speech \\
in your community. Should he be allowed to speak, or not? \\
Asked between 1990 and 2014 \\
GSS Mnemonic: SPKHOMO \\
And what about a man who admits that he is a homosexual? Should \\
such a person be allowed to teach in a college or university, or not? \\
Asked between 1990 and 2014 \\
GSS Mnemonic: COLHOMO \\
COLLEGE
\end{tabular}

Note: Questions come from the pooled General Social Survey, 1990 to 2014

those working full-time and part-time. ${ }^{18}$ I find significant differences in how ENDAs impacted full-time and part-time workers. For gay men who were working more than 30 hours a week, ENDAs increased their wages by 3.0\%-3.2\%. Gay men who were working part-time (less than 30 hours a week) did not experience a wage increase after an ENDA was passed. For lesbian women, the pattern is flipped. There is weak evidence that lesbian women working part-time may have received wage increases. I find a $12.0 \%$ increase in hourly wages of lesbian women working part-time, but no significant effect on annual income from wages. The effects for full-time lesbian women are negative for both groups, but not significant at the 5\% level.

\section{Robustness Checks and Threats to Validity}

So far the results have shown increases in the wages of gay men and declines in employment and hours worked for lesbian women as a result of passing an ENDA. This next section addresses potential threats to the validity of these results.

The differences-in-differences-in-differences methodology rests on the assumption that the unobservables are uncorrelated with the treatment. Error terms of the wage equation may not be parallel if the level of discrimination is changing faster in states with employment protections than in states without employment protections.

\footnotetext{
${ }^{18}$ See Appendix Table 15 for the results broken out by provision.
} 


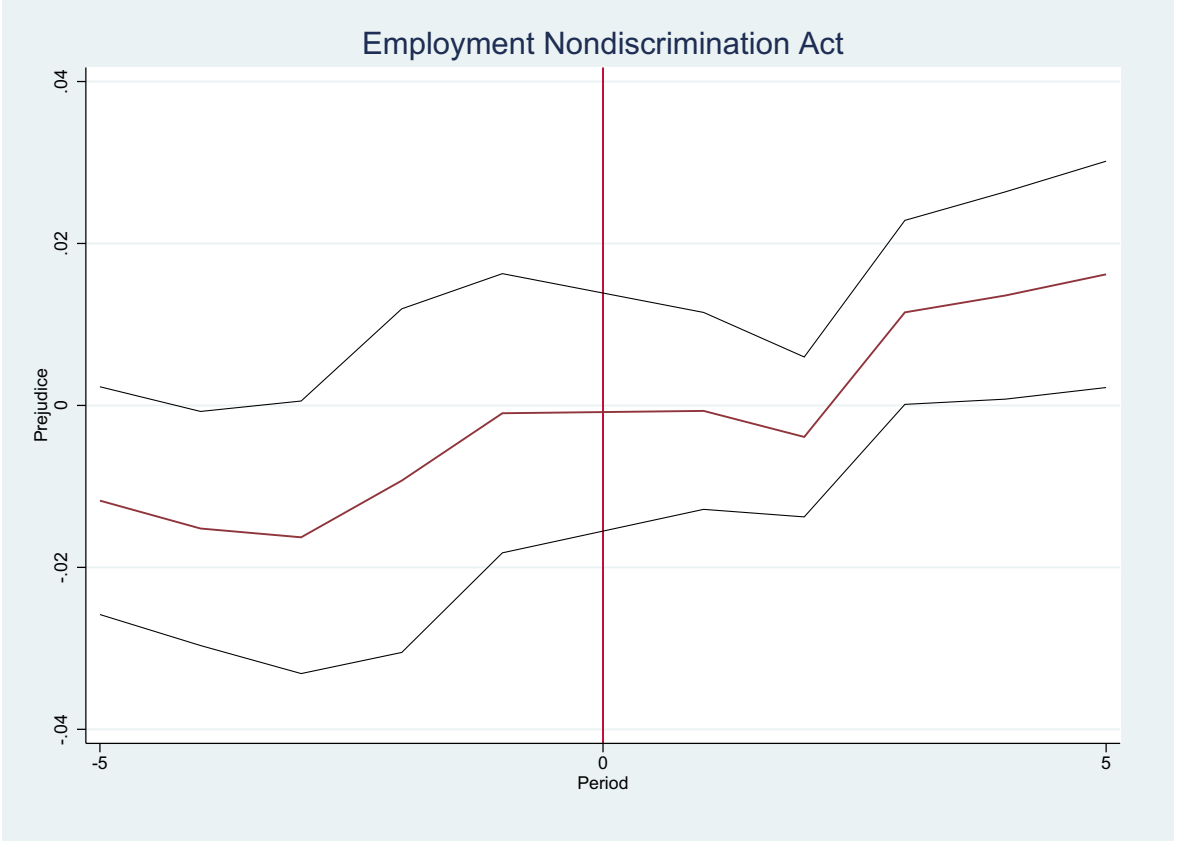

Fig. 2 Change in Prejudice Relative to Year of Passage for ENDAs Note: Data comes from the 1990 through 2014 General Social Surveys. Prejudice is calculated as the percent of individuals in a Census division that give the most prejudice answers to questions regarding homosexuality in the General Social Survey. See Table 6 for the questions asked and the possible answers

Using responses from the General Social Survey, it is possible to calculate the percent of individuals that express prejudiced sentiments to questions about homosexuality. Research has shown that the wages of gay men are correlated with the share of individuals in a state who give prejudiced answers to questions about homosexuality in the General Social Survey (Pride 2017). ${ }^{19}$

There is no publicly available data on prejudice at the state level, so the publicly available Census division level data is used. In the General Social Survey, there are four questions about homosexuality asked in every wave. Table 6 details the text of each question and the possible answers. The questions in the GSS ask a respondent's feelings about sexual relations between adults of the same gender, whether they support homosexuals teaching in colleges, whether they support books promoting homosexuality to be housed in public libraries, and whether homosexuals should be able to give speeches in favor of homosexuality in public. For every Census division, I calculate the share of individuals giving the most prejudiced answer to all the questions. Since the General Social Survey is asked every two years, I impute the

\footnotetext{
${ }^{19}$ Research into wage penalties for black men has also found significant correlations between wage penalties and prejudice in the General Social Survey (Bond and Lehmann 2015; Charles and Guryan 2008). The calculation of the share prejudiced used here is similar to the definition of prejudiced used in Bond and Lehmann (2015).
} 
odd years using the mean of the preceding and succeeding shares of prejudiced individuals. I then estimate the rate at which states that pass an ENDA are growing less prejudiced relative to other states.

To test the pre-trends, I regress the share of GSS respondents giving all prejudiced answers (Prejudice $s, t$ ) on dummies for the year relative to the passage of an ENDA $\left(\tau_{t}\right)$, where $\left(\tau_{0}\right)$ is equal to the year of passage and is the omitted category in the regression. I also include state and year fixed effects $\left(\delta_{s}\right.$ and $\left.\delta_{t}\right)$.

$$
\text { Prejudice }, t=\beta+\sum_{t=-5}^{-1} \tau_{t}+\sum_{t=1}^{5} \tau_{t}+\delta_{t} I_{t}+\delta_{s} I_{s}+\epsilon_{s, t}
$$

Figure 2 shows how the pre-trends in prejudice are evolving relative to the passage of an ENDA. I find no evidence states that pass an ENDA experience faster declines in prejudice. The share of individuals expressing prejudice against the LGBT community rises slightly four and five years after the passage of an ENDA, suggesting the passage of ENDAs may result in a small backlash against the LGBT community. ${ }^{20}$

The second issue potentially biasing the results is that the estimates for log hourly wages are conditional on being in the labor market. It is possible that selection into the labor market is not random. Note however that for the selection correction to an effect on the estimation of $\beta_{2}$ the selection must occur differently in states with and without an ENDA. In the data, there appears to be little evidence of this. For both gay men and lesbian women, the rate of selection does not vary much across states with different laws. Neither does the rate of selection into the labor market appear to vary by gender. Approximately, $82 \%$ of gay men and lesbian women report earnings and $18 \%$ do not. The differences between homosexuals and heterosexuals are equally stable. The share of gay men reporting they did not work the previous year is $3 \%$ higher than married heterosexual men in states with an ENDA, in states without an ENDA the gap is $2 \%$. In states with an ENDA, lesbian women are $14 \%$ more likely to report wages, and in states with no ENDA the gap is also approximately $14 \%$. Therefore, while $\beta_{1}$ is likely to be sensitive to controlling for selection (especially amongst women), the effects on $\beta_{2}$ will be small.

To correct the estimates for selection, I use a semi-parametric estimation strategy. I regress the indicator for being employed $\left(E_{i s t}\right)$ on all of the controls used in the baseline estimation. ${ }^{21}$ I also include additional controls: the number of children an individual has $\left(K i d s_{i, s, t}\right)$ and a dummy for whether any of those children are under the age of two $\left(\right.$ Young $\left._{i, s, t}\right)$.

$$
\begin{array}{r}
E_{i s t}=\beta_{0}+\beta_{1} \text { Homo }_{i s t}+\beta_{2}\left(\text { Homo }_{i s t} \times E N D A_{s t}\right)+I_{s} \gamma_{s}+I_{t} \gamma_{t} \\
+\left(I_{s} \times I_{t}\right) \gamma_{s t}+\left(\text { Homo }_{i s t} \times I_{s}\right) \theta_{H, s}+\left(\text { Homo }_{i s t} \times I_{t}\right) \theta_{H, t}+\mathbf{X}_{i s t}^{\prime} \delta \\
+\alpha_{1} \text { Kids }_{i, s, t}+\alpha_{2} \text { Young }_{i, s, t}+\epsilon_{i s t}
\end{array}
$$

Using the estimated coefficients from Eq. 4, I estimate the predicted probability that an individual would be employed $(\rho)$. I use a fifth order polynomial of this

\footnotetext{
${ }^{20}$ I further test this assumption by including state linear time trends and a separate time trend for gay men nationally. When I do this the results are nearly identical to the baseline estimation. Passing an ENDA resulted in a $3.0 \%$ increase in wages, significant at the $5 \%$ level. Simply using state by year fixed effects and gay by year fixed effects resulted in an estimate of $2.7 \%$, also significant at the $5 \%$ level.

${ }^{21}$ Employed is defined as reporting income from wages in the past year and being in the labor force.
} 
Table 7 Robustness of results on wages to controlling for selection into employment

\begin{tabular}{lllll}
\hline & $\begin{array}{l}\text { Men } \\
\text { Ln annual income } \\
(1)\end{array}$ & $\begin{array}{l}\text { Ln hourly wages } \\
(2)\end{array}$ & $\begin{array}{l}\text { Women annual income } \\
\text { Ln }\end{array}$ & $\begin{array}{l}\text { Ln hourly wage } \\
(4)\end{array}$ \\
\hline Homosexual $\times$ ENDA & $\begin{array}{l}0.018 \\
(0.013)\end{array}$ & $\begin{array}{l}0.029^{*} \\
(0.012)\end{array}$ & -0.019 & -0.003 \\
Observations & $6,172,273$ & $6,172,273$ & $5,061,060$ & $(0.013)$ \\
\hline
\end{tabular}

$* * * \mathrm{p}<0.001, * * \mathrm{p}<0.01, * \mathrm{p}<0.05$

Note: Author's calculations based on data from the 2008 through 2014 American Community Surveys $1 \%$ PUMS, the 1990 Decennial Census 5\% PUMS, and the 2000 Decennial Census 5\% PUMS. The sample is restricted to adults, older than 22 and younger than 65. Individuals are either married heterosexuals or cohabiting gay men or lesbian women. Individuals who have moved between states in the past year are not included in the analysis. Annual income and hourly wages are in constant 1999 dollars. All regressions are estimated using OLS and include demographic and occupation controls, state fixed effects, year fixed effects, and state-by-year fixed effects. For a full list of control variables, see Table 9. Standard errors clustered at the state level are in parentheses

predicted probability as a control in the wage regression to control for selection into the labor market (5).

$$
\begin{array}{r}
Y_{i s t}=\beta_{0}+\beta_{1} \text { Homo }_{i s t}+\beta_{2}\left(\text { Homo }_{i s t} \times E N D A_{s t}\right)+I_{s} \gamma_{s}+I_{t} \gamma_{t} \\
+\left(I_{s} \times I_{t}\right) \gamma_{s t}+\left(\text { Homo }_{i s t} \times I_{s}\right) \theta_{H, s}+\left(\text { Homo }_{i s t} \times I_{t}\right) \theta_{H, t}+\mathbf{X}_{i s t}^{\prime} \delta \\
+\rho_{i, s, t}+\rho_{i, s, t}^{2}+\rho_{i, s, t}^{3}+\rho_{i, s, t}^{4}+\rho_{i, s, t}^{5}+\epsilon_{i s t}
\end{array}
$$

I show in Table 7 that selection did not have a significant effect on the results. ${ }^{22}$ In column 1, I report the results for the average effect of an ENDA for gay men. The results do not appear to have been driven by selection into the labor force. The effect of an ENDA conditional on selection into employment remains similar to what it was in the baseline estimation. The effect on log annual income does not change if one controls for selection. The effect of an ENDA on log hourly wages increases slightly to $2.9 \% .^{23}$ The results for lesbian women remain the same.

The third potential concern is that at the same time that states were passing ENDAs, some states were also granting the right of same-sex marriage to gay men and lesbian women. It is possible that the passage of same-sex marriage increases the wages of gay men and lesbian women, though the previous literature has not found there is a wage premium associated with cohabiting for gay men (Zavodny 2007). Table 8 reports the results controlling for the passage of same-sex marriage. The top panel of Table 8 shows the results for men. After controlling for the passage of samesex marriage, the average effect of an ENDA remains relatively unchanged at $2.8 \%$. The results for employment and hours worked are still not statistically significant. The bottom panel of Table 8 reports the results for women. The passage of samesex marriage similarly does not change the results in a significant way. There is still

\footnotetext{
${ }^{22}$ It is possible to control for selection using other possible techniques. When one uses a Heckman twostep process to correct for the selection, the results are qualitatively the same as the semi-nonparametric method described above.

${ }^{23}$ Appendix Table 11 reports the effect of controlling for selection on the results for legal provisions.
} 
Table 8 Robustness of results to controlling for same-sex marriage

\begin{tabular}{|c|c|c|c|c|}
\hline Panel A. & $\begin{array}{l}\text { Men } \\
\text { Ln annual income } \\
\text { (1) }\end{array}$ & $\begin{array}{l}\text { Ln hourly wages } \\
\text { (2) }\end{array}$ & $\begin{array}{l}\text { Employment } \\
\text { (3) }\end{array}$ & $\begin{array}{l}\text { Hours worked } \\
\text { (4) }\end{array}$ \\
\hline Gay $\times$ ENDA & $\begin{array}{l}0.017 \\
(0.013)\end{array}$ & $\begin{array}{l}0.028^{*} \\
(0.012)\end{array}$ & $\begin{array}{l}0.005 \\
(0.005)\end{array}$ & $\begin{array}{l}0.190 \\
(0.194)\end{array}$ \\
\hline Observations & $\begin{array}{l}6,172,273 \\
\text { Women }\end{array}$ & $6,172,273$ & $7,660,401$ & $7,660,401$ \\
\hline Panel B. & $\begin{array}{l}\text { Ln annual income } \\
\text { (1) }\end{array}$ & $\begin{array}{l}\text { Ln hourly wages } \\
\text { (2) }\end{array}$ & $\begin{array}{l}\text { Employment } \\
\text { (3) }\end{array}$ & $\begin{array}{l}\text { Hours worked } \\
\text { (4) }\end{array}$ \\
\hline Lesbian $\times$ ENDA & $\begin{array}{l}-0.018 \\
(0.016)\end{array}$ & $\begin{array}{l}-0.003 \\
(0.013)\end{array}$ & $\begin{array}{l}-0.017^{*} \\
(0.008)\end{array}$ & $\begin{array}{l}-0.738^{* *} \\
(0.251)\end{array}$ \\
\hline Observations & $5,061,060$ & $5,061,060$ & $8,060,889$ & $8,060,889$ \\
\hline
\end{tabular}

$* * * \mathrm{p}<0.001, * * \mathrm{p}<0.01, * \mathrm{p}<0.05$

Note: Author's calculations based on data from the 2008 through 2014 American Community Surveys 1\% PUMS, the 1990 Decennial Census 5\% PUMS, and the 2000 Decennial Census 5\% PUMS. The sample is restricted to adults, older than 22 and younger than 65. Individuals are either married heterosexuals or cohabiting gay men or lesbian women. Individuals who have moved between states in the past year are not included in the analysis. Annual income and hourly wages are in constant 1999 dollars. All regressions are estimated using OLS and include demographic and occupation controls, state fixed effects, year fixed effects, and state-by-year fixed effects. For a full list of control variables, see Table 9. Standard errors clustered at the state level are in parentheses

a negative and significant effect of ENDAs on employment and hours worked for lesbian women. ${ }^{24}$

\section{Conclusion}

In this paper, I explored the effect that the passage of ENDAs at the state-level had on the labor market outcomes of gay men and lesbian women. The results showed that ENDAs led to a decline in the wage gap between gay men and married heterosexual men, but also reduced the employment of lesbian women. The fact that gay men would benefit from the passage of an ENDA and lesbian women would suffer from the passage of an ENDA can be interpreted as employers reducing the importance of sexual orientation in employment decisions. Because lesbian women may be favored over heterosexual women, the passage of an ENDA reduces the benefits they experience and increases the employment prospects of married heterosexual women. The passage of an ENDA increases the employment prospects of gay men relative to heterosexual men.

When I treat all ENDAs as identical as was done in the previous literature, I find ENDAs increased the wages of gay men by $2.7 \%$ and had no effect on employment and hours worked per week. This is similar to the effects in Baumle and Poston (2011), which found ENDAs increased wages by 2.6\%. The results are also similar to the magnitudes found in the General Social Survey by Martell (2013).

\footnotetext{
${ }^{24}$ Appendix Table 16 reports the effect of controlling for same-sex marriage on the results for legal provisions.
} 
The key contribution of this paper is that I show the effects of ENDAs for gay men are concentrated in a handful states. The evidence suggests that strong and weak laws had different effects that reduced the aggregate effect observed in previous research (Baumle and Poston 2011; Klawitter and Flatt 1998; Klawitter 2011; Martell 2013). By looking at the state-level variation in these non-discrimination laws, I can estimate the effect of strong versus weak laws. For gay men, the effects of the law depend heavily on the structure of the law. If I look at what would be considered a strong law and a weak law separately, I find that strong laws had larger wage increases and larger employment increases. Based on the estimates from Panel B of Table 3, a strong law (e.g. a law with compensatory damages, punitive damages, attorney's fees, a size minimum of 1 , and a statute of limitations of 1 year) saw an average increase in annual wages of $12.3 \%$ and an increase in employment of $0.8 \%$. A weak law (e.g., a law with no compensatory damages and no punitive damages, a size minimum of 15 employees, and a statute of limitations of 180 days) saw no increase in wages and a decrease in employment of $0.4 \%$.

For lesbian women, the specific provisions of the laws have little effect on their labor market outcomes (Table 4). The average law had no effect on wages, but decreased employment by $1.7 \%$ and decreased hours by 0.733 hours. States with punitive damages saw larger declines in hours worked than states without punitive damages.

These results highlight the care that must be taken when crafting a law to protect a marginalized group. Simply using the same template as existing laws that protect employees against racial and gender discrimination may be detrimental. The most current version of the federal Employment Non-Discrimination Act to pass the Senate in 2013 had a statute of limitations of 180 days. This is lower than the average of state statutes of limitations by two months. The employer size minimum in the proposed ENDA is 15 employees. This is ten more employees than the average state law. The federal ENDA allows for compensatory and punitive damages and attorney's fees to be awarded. Using the results from Tables 3 and 4, it is possible to calculate the effect of the federal law. For gay men, this law would have an estimated wage effect of $7.4 \%-7.9 \%$ (depending on whether one uses annual income from wages or hourly wages) and an estimated employment effect of $-0.4 \%$. For lesbian women, this law would decrease employment by $1.7 \%$ and decrease hours worked by 2.179 hours. These estimates suggest that policymakers must think carefully about the strength of the provisions when crafting the bill.

The effect of these employment protection laws can be very nuanced. Future research into similar laws where state laws are not constrained by federal protections, such as pay secrecy bans or transgender protections, need to take the legal differences into account when estimating the effect of the laws. Failure to do so may result in inconclusive results that are driven by the differences between weak and strong laws. My results also suggest that other policies that are implemented differently across states may experience similar differences depending on the structure of the implementation.

Acknowledgments I would like to thank David Neumark, Marianne Bitler, Damon Clark, and Yingying Dong for their comments and feedback. I would also like to thank participants at APPAM, PAA, and UCI for their feedback. Data files and do-files for STATA are available from the author upon request. All errors are my own. I have no affiliations with or involvement in any organization or entity with any financial interest or non-financial interest in the subject matter or materials discussed in this manuscript. 
Open Access This article is distributed under the terms of the Creative Commons Attribution 4.0 International License (http://creativecommons.org/licenses/by/4.0/), which permits unrestricted use, distribution, and reproduction in any medium, provided you give appropriate credit to the original author(s) and the source, provide a link to the Creative Commons license, and indicate if changes were made.

\section{Appendix}

Table 9 List of variables

Variable Definition

Dependent Variable:

Annual earnings

Natural logarithm of hourly earnings (= total annual salary earnings

divided by total number of hours worked per year) in previous year,

in constant 1999 USD

Usual hours worked per week

Employed

Control Variables:

Sexual Orientation ( $=1$ if Homosexual, $=0$ if Heterosexual)

Experience $($ Potential, =Age - Schooling -5 )

Experience Squared

Black

Non-Native English Speaker (=1 if True, $=0$ if False)

Children ( $=1$ if True, $=0$ if False)

Children Under 5 Years Old ( $=1$ if True, $=0$ if False)

Years of Schooling

Years of Schooling Squared

High School Graduate

Associate's Degree

Bachelor's Degree

Master's Degree

Ph.D. or Professional Degree

Two Digit Census Occupation Code

Two Digit Census Industry Code

Urban ( $=1$ if True, $=0$ if False)

State

Year

Treatment Variables

Employment Non-Discrimination Act Protections for Homosexuals in State ( $=1$ if True, $=0$ if False)

Compensatory Damages ( $=1$ if True, $=0$ if False)

Punitive Damages $(=1$ if True, $=0$ if False)

Statute of Limitations (Relative to Average)

Employer Size Minimum (Relative to Average)

Attorney's Fees $(=1$ if True, $=0$ if False)

Note: Sources of all variables are the 2008 through 2014 American Community Survey 1-Year Sample, the 1990 to 2012 General Social Surveys, and Sears et al. (2009) 


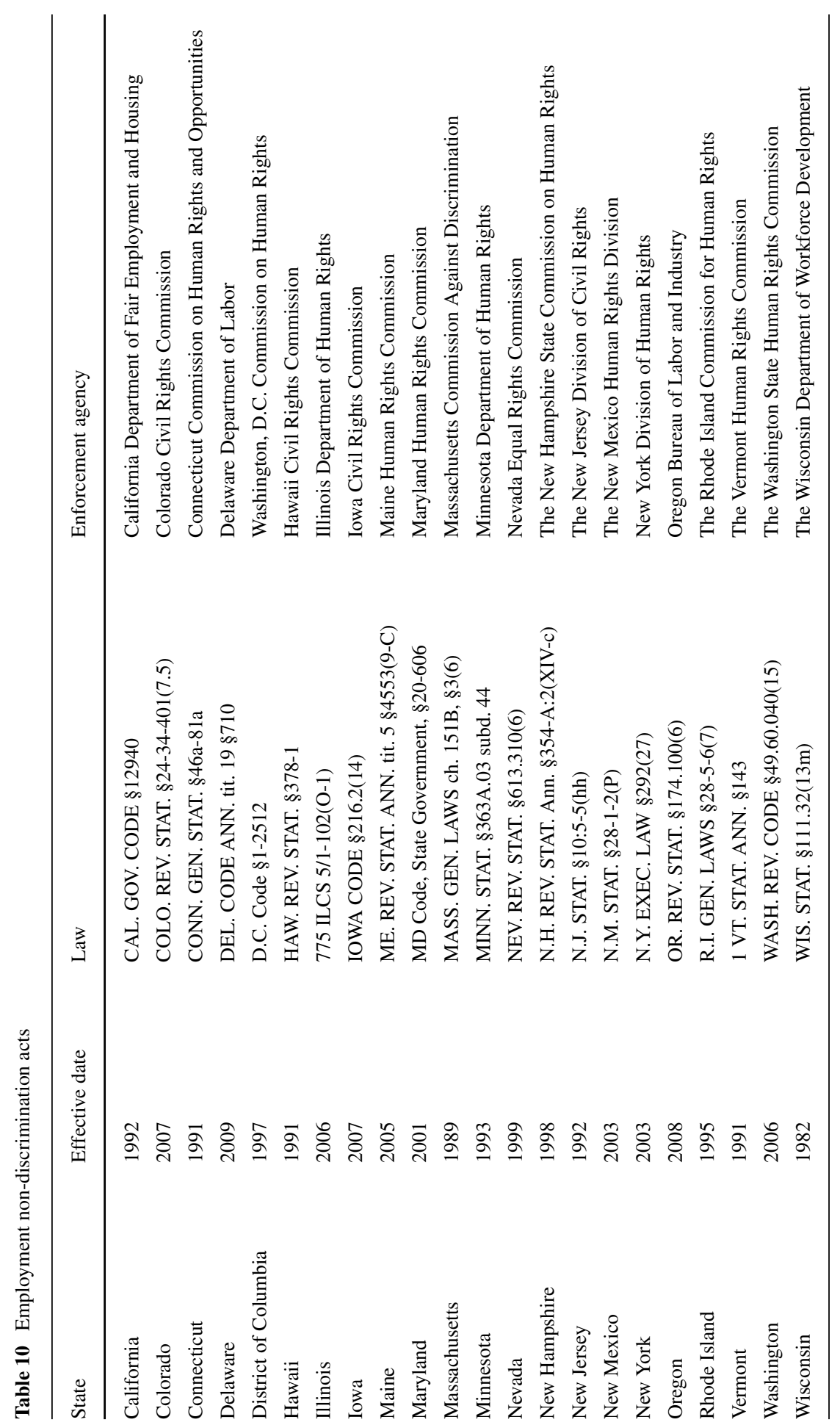




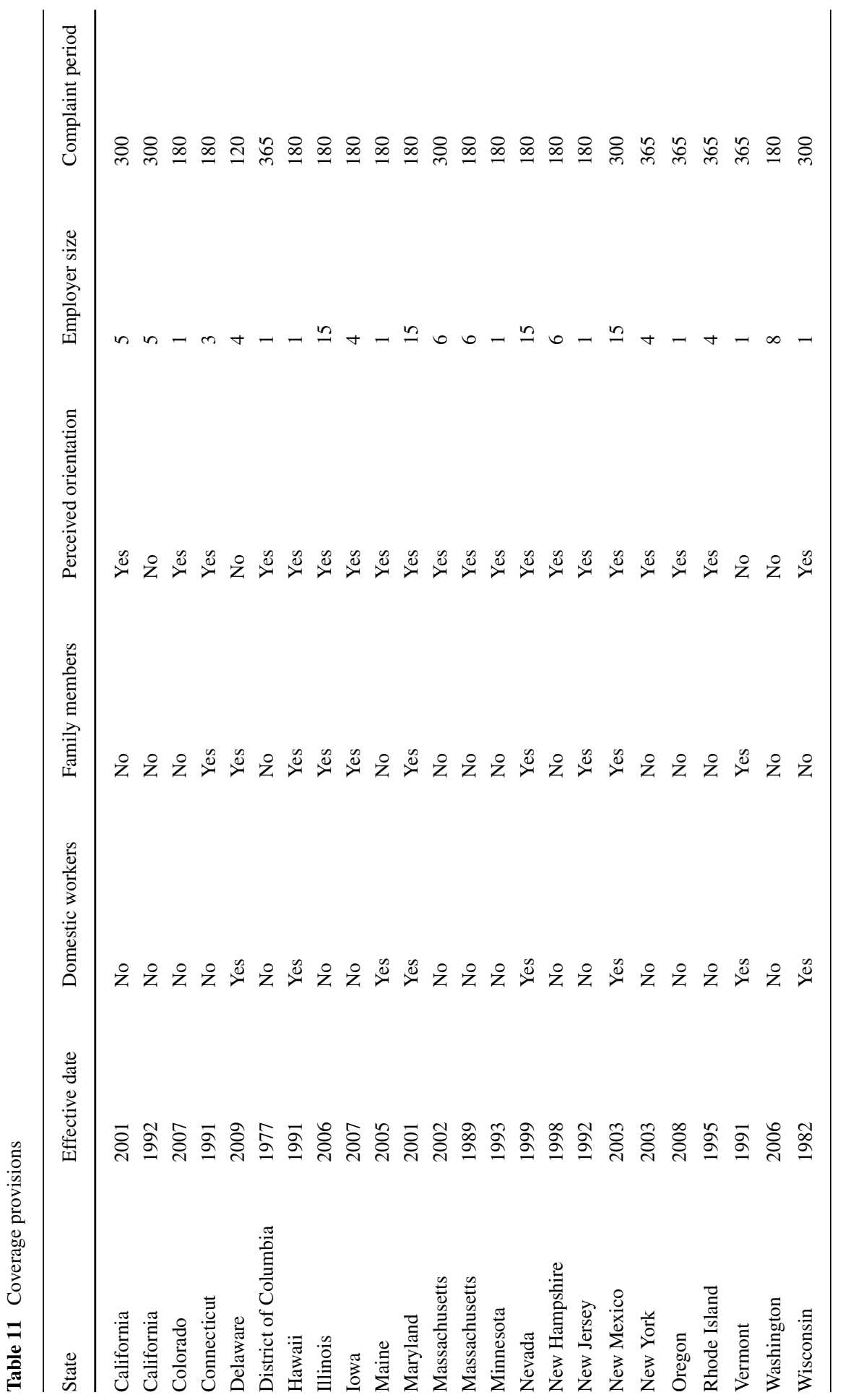




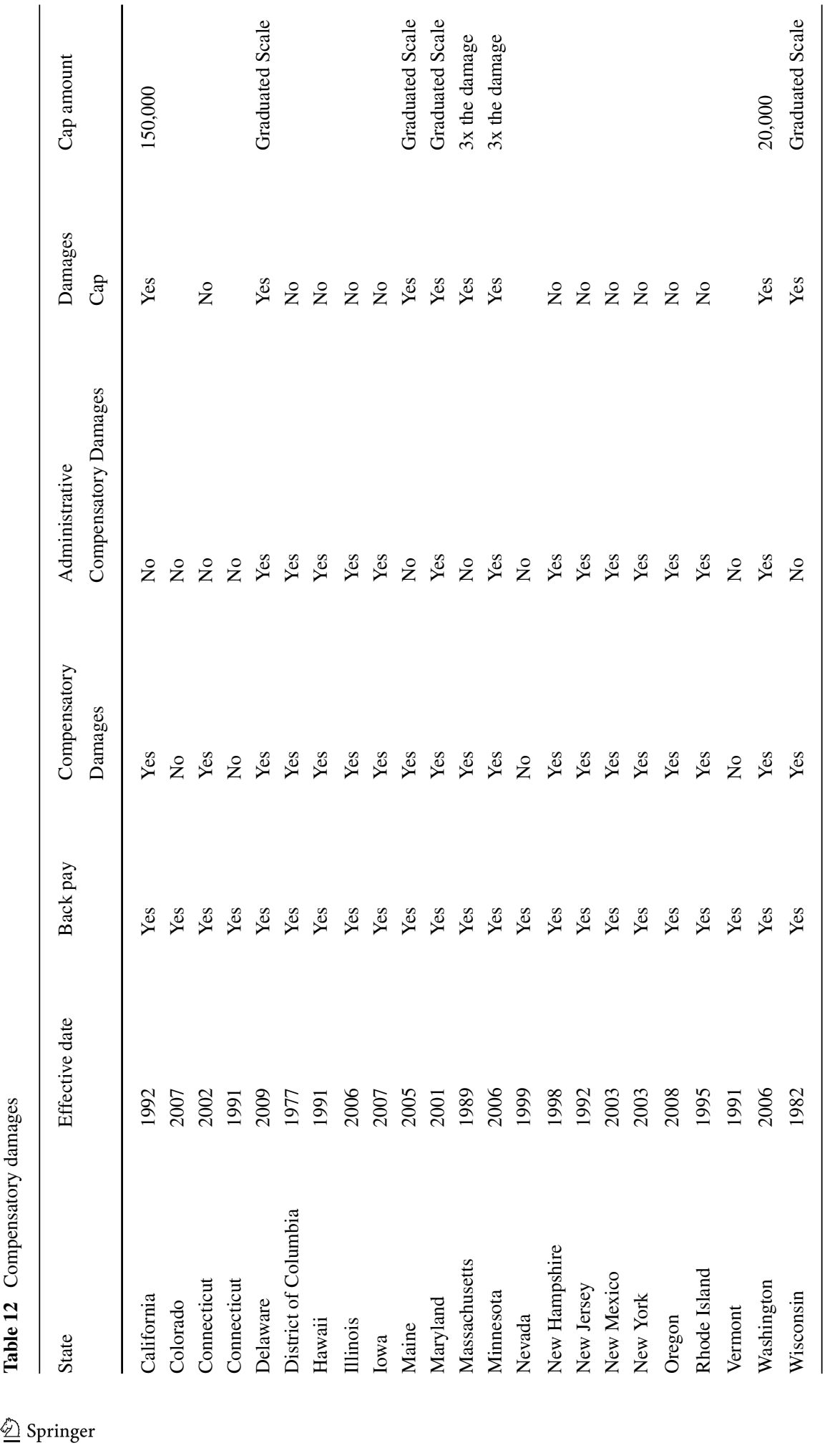




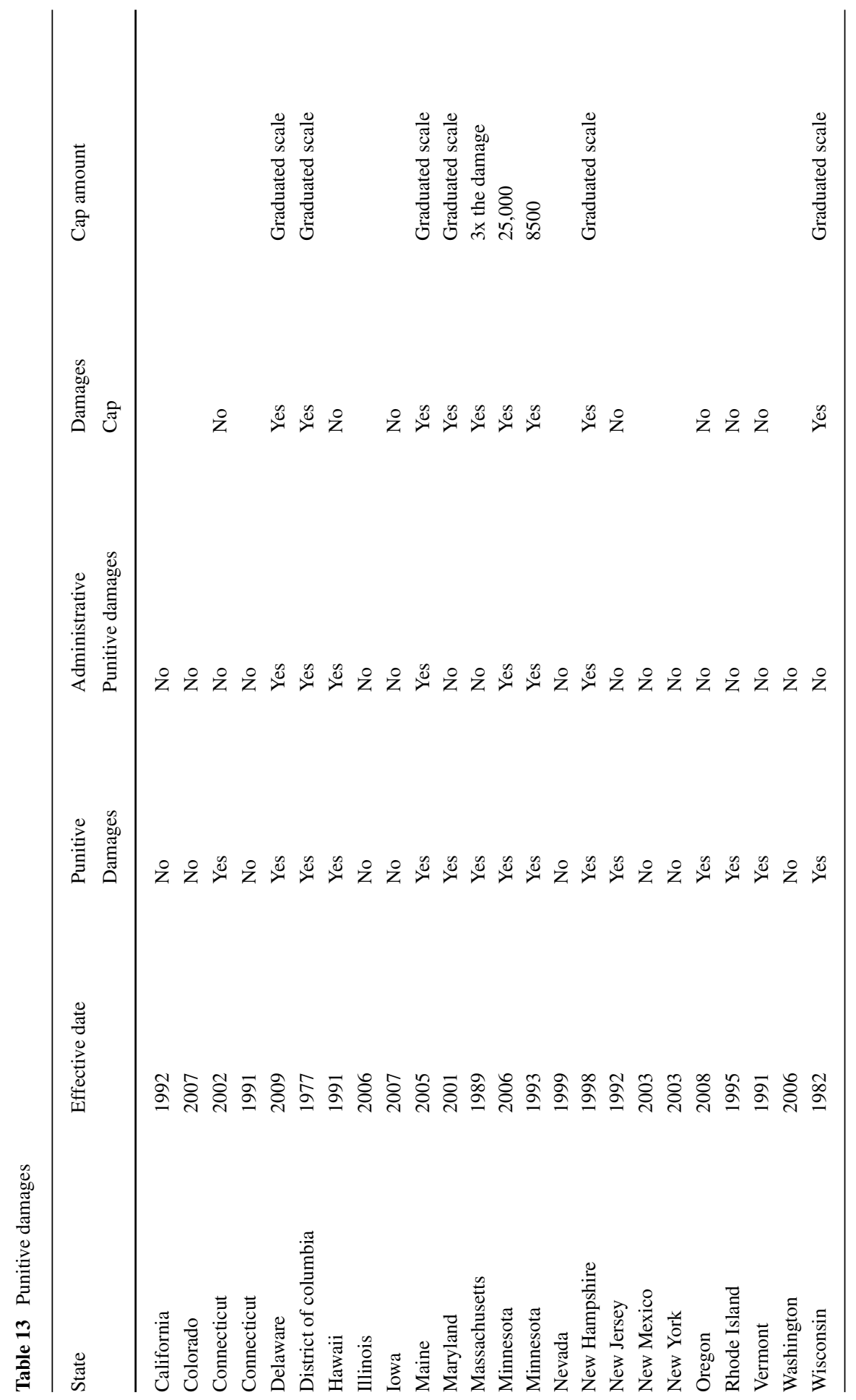




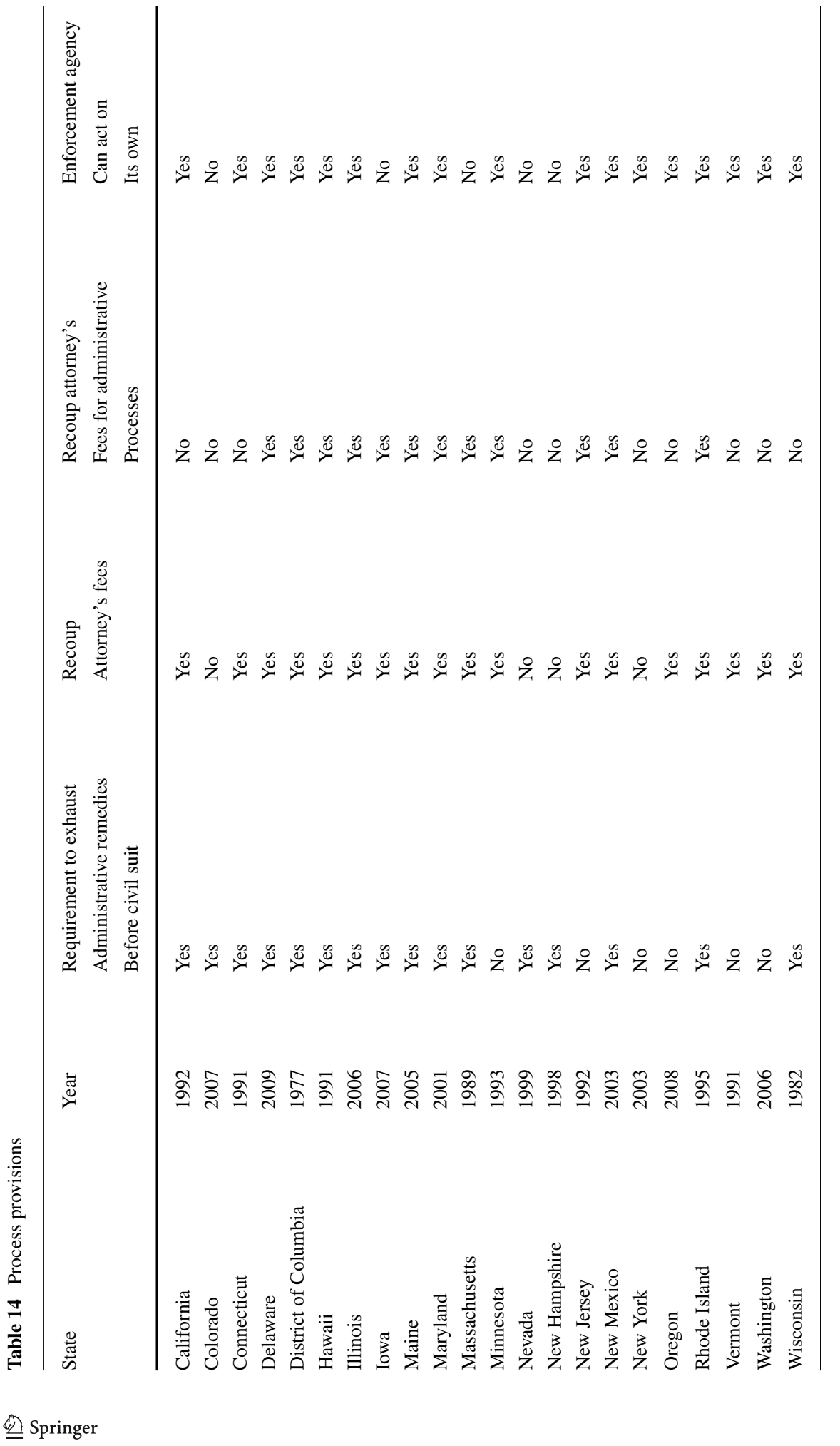




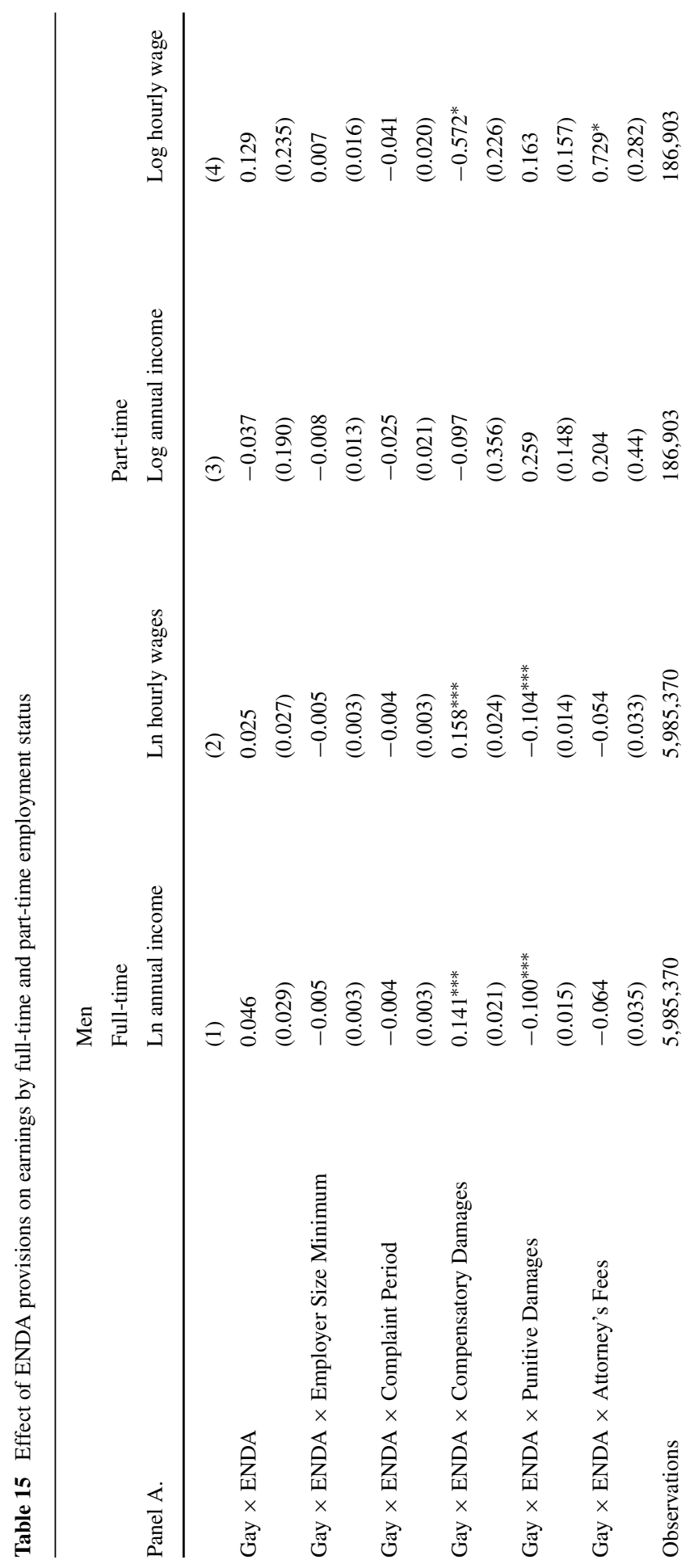




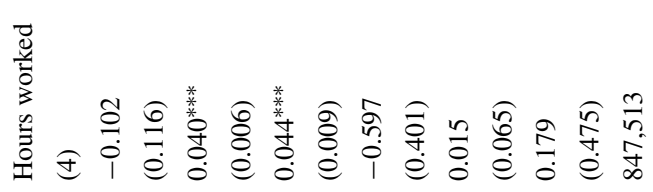

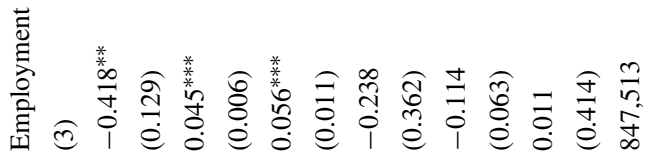

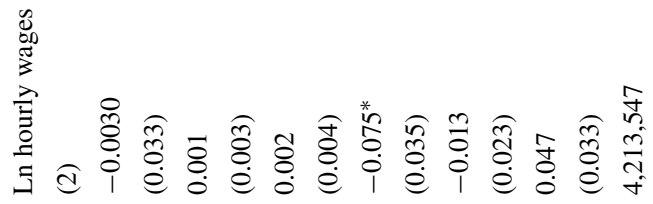

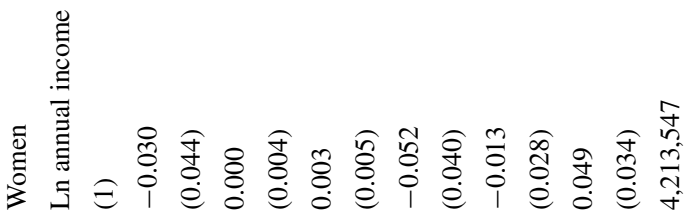

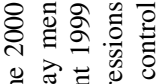

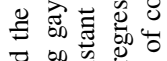

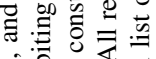

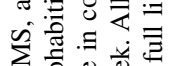

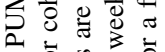

。ํำ

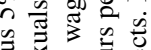

死离

U:

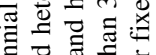

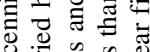

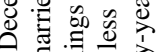

药

ऽ。

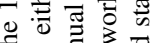

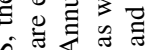

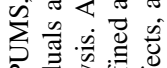

훙 충

을 纪

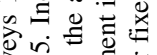

记寻击

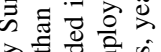

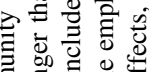

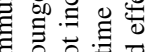

항호항

Uृ

ฮั๊

政的节

安菏的哭

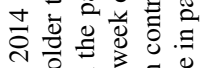

ธิ

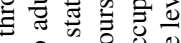

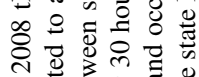

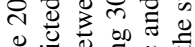

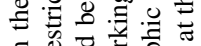

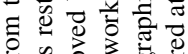

응 30

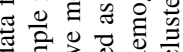

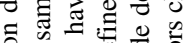

웜워

일

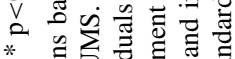

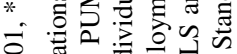

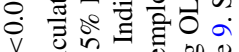

v $\frac{0}{\pi}$ in

*

8 쿵

v 


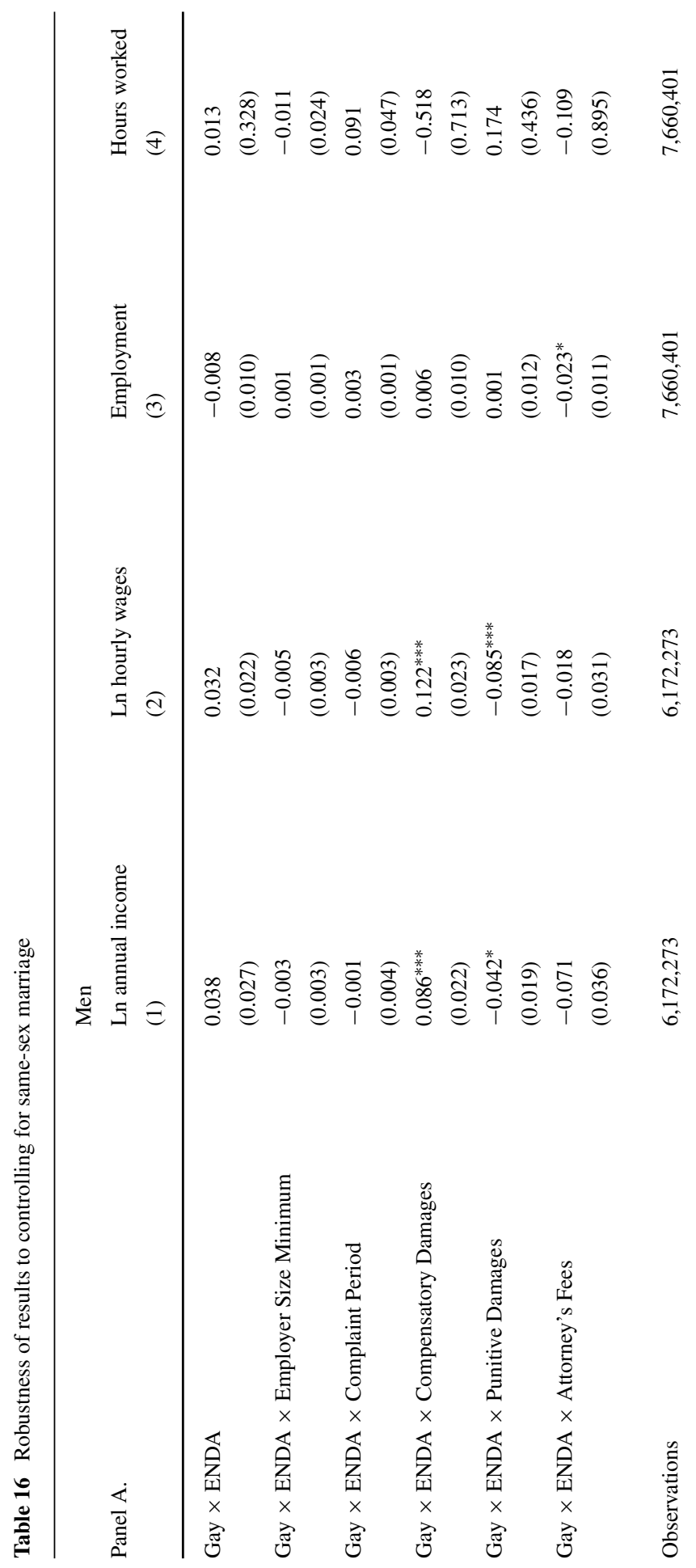




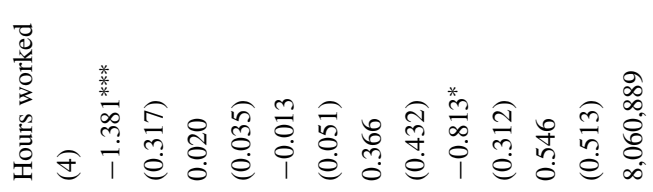

言

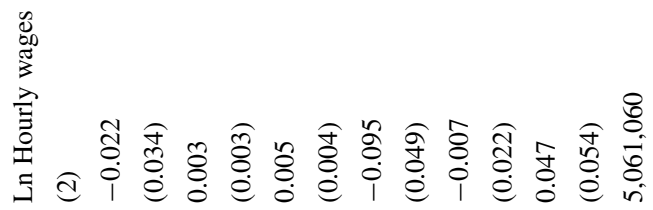

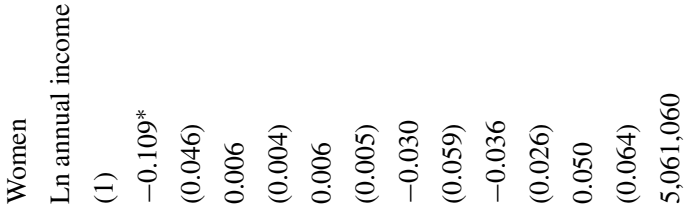

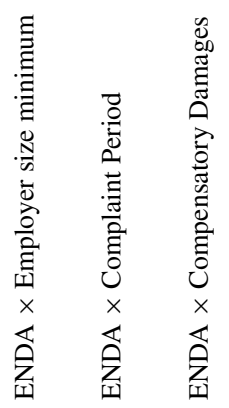

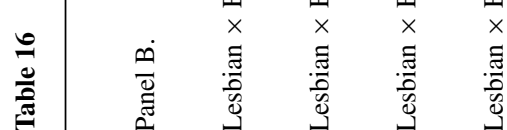

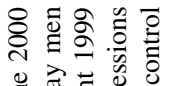

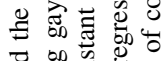

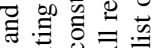

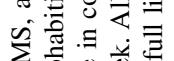

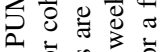

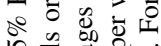

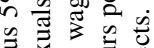

文諝

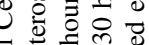

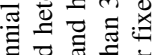

政

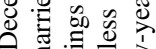

ह

可政

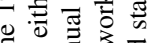

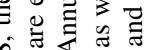

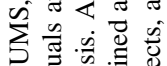

2

은

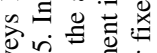

ㄴ.

क

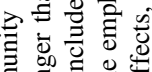

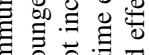

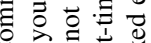

Uु

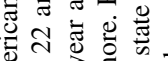

政

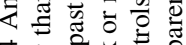

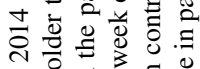

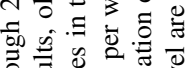

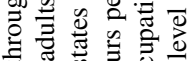

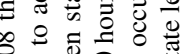

웡

包.

政

항

.

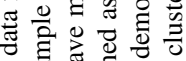

吅

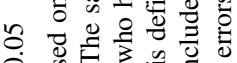

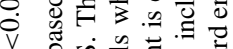

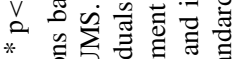

을

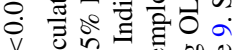

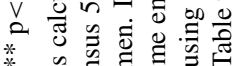

*

8 잉

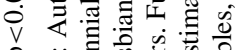

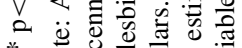


Table 17 Robustness of results on wages to controlling for selection into labor market

\begin{tabular}{|c|c|c|}
\hline Panel A. & $\begin{array}{l}\text { Men } \\
\text { Ln annual income } \\
\text { (1) }\end{array}$ & $\begin{array}{l}\text { Ln Hourly wages } \\
\text { (2) }\end{array}$ \\
\hline Gay $\times$ ENDA & $\begin{array}{l}0.040 \\
(0.027)\end{array}$ & $\begin{array}{l}0.029 \\
(0.021)\end{array}$ \\
\hline Gay $\times$ ENDA $\times$ Employer size minimum & $\begin{array}{l}-0.003 \\
(0.003)\end{array}$ & $\begin{array}{l}-0.005 \\
(0.003)\end{array}$ \\
\hline Gay $\times$ ENDA $\times$ Complaint period & $\begin{array}{l}-0.001 \\
(0.004)\end{array}$ & $\begin{array}{l}-0.006 \\
(0.003)\end{array}$ \\
\hline Gay $\times$ ENDA $\times$ Compensatory damages & $\begin{array}{l}0.084^{* * *} \\
(0.021)\end{array}$ & $\begin{array}{l}0.128^{* * *} \\
(0.021)\end{array}$ \\
\hline Gay $\times$ ENDA $\times$ Punitive damages & $\begin{array}{l}-0.042^{*} \\
(0.020)\end{array}$ & $\begin{array}{l}-0.080^{* * *} \\
(0.018)\end{array}$ \\
\hline Gay $\times$ ENDA $\times$ Attorney's fees & $\begin{array}{l}-0.069^{*} \\
(0.033)\end{array}$ & $\begin{array}{l}-0.029 \\
(0.031)\end{array}$ \\
\hline Observations & $\begin{array}{l}6,172,273 \\
\text { Women }\end{array}$ & $6,172,273$ \\
\hline Panel B. & $\begin{array}{l}\text { Ln annual income } \\
\text { (1) }\end{array}$ & $\begin{array}{l}\text { Ln hourly wages } \\
\text { (2) }\end{array}$ \\
\hline Lesbian $\times$ ENDA & $\begin{array}{l}-0.115^{*} \\
(0.049)\end{array}$ & $\begin{array}{l}-0.027 \\
(0.038)\end{array}$ \\
\hline Lesbian $\times$ ENDA $\times$ Employer size minimum & $\begin{array}{l}0.005 \\
(0.004)\end{array}$ & $\begin{array}{l}0.004 \\
(0.003)\end{array}$ \\
\hline Lesbian $\times$ ENDA $\times$ Complaint period & $\begin{array}{l}0.007 \\
(0.006)\end{array}$ & $\begin{array}{l}0.006 \\
(0.005)\end{array}$ \\
\hline Lesbian $\times$ ENDA $\times$ Compensatory damages & $\begin{array}{l}-0.017 \\
(0.054)\end{array}$ & $\begin{array}{l}-0.088 \\
(0.046)\end{array}$ \\
\hline Lesbian $\times$ ENDA $\times$ Punitive damages & $\begin{array}{l}-0.041 \\
(0.027)\end{array}$ & $\begin{array}{l}-0.007 \\
(0.023)\end{array}$ \\
\hline Lesbian $\times$ ENDA $\times$ Attorney's fees & $\begin{array}{l}0.034 \\
(0.064)\end{array}$ & $\begin{array}{l}0.033 \\
(0.052)\end{array}$ \\
\hline Observations & $5,061,060$ & $5,061,060$ \\
\hline
\end{tabular}

*** $\mathrm{p}<0.001$, ** $\mathrm{p}<0.01, * \mathrm{p}<0.05$

Note: Author's calculations based on data from the 2008 through 2014 American Community Surveys 1\% PUMS, the 1990 Decennial Census 5\% PUMS, and the 2000 Decennial Census 5\% PUMS. The sample is restricted to adults, older than 22 and younger than 65 . Individuals are either married heterosexuals or cohabiting gay men or lesbian women. Individuals who have moved between states in the past year are not included in the analysis. Annual earnings and hourly wages are in constant 1999 dollars. Fulltime employment is defined as working 30 hours per week or more. Part-time employment is defined as working less than 30 hours per week. All regressions are estimated using OLS and include demographic and occupation controls, state fixed effects, year fixed effects, and state-by-year fixed effects. For a full list of control variables, see Table 9. Standard errors clustered at the state level are in parentheses 


\section{References}

Acemoglu D, Angrist JD (2001) Consequences of Employment Protection? The Case of the Americans with Disabilities Act. J Polit Econ 109(5):915-957

Adams SJ (2004) Age discrimination legislation and the employment of older workers. Labour Econ 11(2):219-241

Allegretto SA, Arthur MM (2001) An Empirical Analysis of Homosexual/Heterosexual Male Earnings Differentials: Unmarried and Unequal? Ind Labor Relat Rev 54(3):631

Antecol H, Steinberger MD (2013) Labor Supply Differences Between Married Heterosexual Women and Partnered Lesbiabs: A Semi-Parametric decomposition approach. Econ Inq 51(1):783-805

Antecol H, Jong A, Steinberger M (2008) The Sexual Orientation Wage Gap: The Role of Occupational Sorting and Human Capital. Ind Labor Relat Rev 61(4):518-543

Badgett MVL (1995) The wage effects of sexual orientation discrimination. Indust Labor Relat Rev 48(4):726-739

Bailey J, Wallace M, Wright B (2013) Are Gay Men and Lesbians Discriminated Against When Applying for Jobs? A Four-City, Internet-Based Field Experiment. J Homosex 60(6):873-894

Baumle AK, Poston DL Jr (2011) The economic cost of homosexuality: Multilevelanalyses. Soc Forces 89(3):1005-1031

Beaudin L (2017) Marriage equality and interstate migration. Appl Econ 49(30):2956-2973

Beegle K, Stock WA (2003) The Labor Market Effects of Disability Discrimination Laws. J Human Resour 38(4):806-859

Black DA, Makar HR, Sanders SG, Taylor LJ (2003) The Earnings Effects of Sexual Orientation. Ind Labor Relat Rev 56(3):449-469

Blandford JM (2003) The nexus of sexual orientation and gender in the determination of earnings. Ind Labor Relat Rev 56(4):622-643

Bloch F (1994) Antidiscrimination Law and Minority Employment: Recruitment Practices and Regulatory Constraints. University of Chicago Press, Chicago

Bond TN, Lehmann J-YK (2015) Prejudice and Racial Matches in Employment, Working Paper

Pride BI (2017) Prejudice, and Wages: An Empirical Assessment of Models of Taste- Based Discrimination for Gay Men, Working Paper

Carpenter CS (2004) New evidence on gay and lesbian household incomes. Contemp Econ Policy 22(1):78-94

Charles K, Guryan J (2008) Prejudice and Wages: An Empirical Assessment of Becker's The Economics of Discrimination. J Polit Econ 116(5):773-808

Collins WJ (2003) The labor market impact of State-Level Anti-Discrimination laws, 1940-1960. Ind Labor Relat Rev 56(2):244-272

Colvin RA, Riccucci NM (2002) Employment nondiscrimation policies: Assessingimplementation and measuring effectiveness. Int J Publ Adm 25(1):95-108

Cushing-Daniels B, Yeung T-Y (2009) Wage Penalties and Sexual Orientation: an Update Using the General Social Survey. Contemp Econ Pol 27(2):164-175

DeLeire T (2000) The wage and employment effects of the americans with disabilities act. J Human Resour 35(4):693-715

Donohue JJ, Heckman J (1991) Continuous Versus Episodic Change: The Impact of Civil Rights Policy on the Economic Status of Blacks. J Econ Lit 29(4):1603-1643

Elmslie B, Tebaldi E (2007) Sexual orientation and labor market discrimination. J Labor Res 28(3):436453

Government Accountability Office (1997) Sexual-Orientation-Based Employment Discrimination: States' Experience With Statutory Prohibitions. GAO-98-7R

Government Accountability Office (2013) Update on State Statutes and Administrative Complaint Data on Employment Discrimination Based on Sexual Orientation and Gender Identity. GAO-13-700R

Human Rights Campaign (2012) Municipality Equality Index 2012. www.hrc.org/mei

Jepsen LK (2007) Comparing the earnings of cohabiting lesbians, cohabiting heterosexual women, and married women: Evidence from the 2000 census. Ind Relat: J Econ Soc 46(4):699-727

Jolls C, Prescott JJ (2004) Disaggregating Employment Protection: The Case of Disability Discrimination. (10740)

Klawitter MM, Flatt V (1998) The Effects of State and Local Antidiscrimination Policies on Earnings for Gays and Lesbians. J Policy Anal Manag 17(4):658-686 
Klawitter M (2011) Multilevel Analysis of the Effects of Antidiscrimination Policies on Earnings by Sexual Orientation. J Policy Anal Manag 30(2):334-358

Klawitter MM (2015) Meta-Analysis Of the effects of sexual orientation on earnings. Ind Relat 54(1):4-32

Kruse D, Schur L (2003) Employment of people with disabilities following the ADA. Ind Relat: J Econ Soc 42(1):31-66

Lahey J (2008) State age protection laws and the age discrimination in employment act. J Law Econ 51(3):433-460

Landes WM (1968) The economics of fair employment laws. J Polit Econ 76(4):507-552

Martell ME (2013) Do ENDAs End Discrimination for Behaviorally Gay Men? J Labor Res 34:147-169

Mishel E (2016) Discrimination against Queer Women in the U.S. Workforce: A résumé Audit Study, Socius: Sociological Research for a Dynamic World, pp 2

Neumark D, Stock WA (1999) age discrimination laws and labor market efficiency. J Political Econ 107(5): 1081-1125

Neumark D, Stock WA (2006) The labor market effects of sex and race discrimination laws. Econ Inq 44(4):385-419

Neumark D, Button P (2014) Did Age Discrimination Protections Help Older Workers Weather the Great Recession? J Policy Anal Manag 33(3):566-601

O'Connell M, Golding G (2006) The Use of First Names to Evaluate Reports of Gender and Its Efffect on the Distribution of Married and Unmarried Couple Households. Paper presented at the Population Association of America Meeting, Los Angeles

O'Connell M, Loftquist D (2009) Counting Same-sex Couples: Official Estimates and Unofficial Guesses. Paper presented at the Population Association of America Meeting, Detroit

Ruggles S, Trent Alexander J, Gendadek K, Goeken R, Schroeder MB, Sobek M (2010) Integrated Public Use Microdata Series: Version 5.0 [Machine-readable database]. University of Minnesota, Minneapolis

Sabia JJ, Orientation S (2014) Wages in young adulthood new evidence from add health. Ind Labor Relat Rev 67(1):239-267

Sears B, Hunter N, Mallory C (2009) Analysis of Scope and Enforcement of State Laws and Executive Orders Prohibiting Employment Discrimination Against LGBT People, The Williams Institute

Sears B, Mallory C (2011) Documented Evidence of Employment Discrimination and Its Effects on LGBT People, The Williams Institute

Tilcsik A (2011) Pride and prejudice: Employment discrimination against openly gay men in the united states. Am J Sociol 117(2):586-626

Ueno K, Vaghela P, Ritter LJ (2014) Sexual Orientation, Internal Migration, and Mental Health during the Transition to Adulthood. J Health Soc Behav 55(4):461-481

Zavodny M (2007) Is there a "Marriage premium" for gay men? Rev Econ Househ 6(4):369-389 